\title{
Fen Bilgisi ve Sınıf Öğretmeni Adaylarının Bilimin Doğasına Yönelik Görüşlerinin İncelenmesi
}

\section{Examination of Views about Nature of Science of Preservice Science and Elementary School Teachers'}

DOI $=$ http: //dx.doi.org/10.17556/jef.52022

\author{
Nilgün YENICE**, Barıș ÖZDEN**, Ceyda BALCI ${ }^{* * *}$
}

\section{Özet}

$\mathrm{Bu}$ araştırmanın amacı fen bilgisi ve sınıf öğretmeni adaylarının bilimin doğasına yönelik görüşlerini incelemektir. Tarama modelinde gerçekleştirilen araştırmanın çalışma grubunu Fen Bilgisi ve Sınıf Öğretmenliği Anabilim Dalının 1. ve 4. sınıflarında öğrenim görmekte olan 142 öğretmen adayı oluşturmuş̧ur. Katılımcıların görüşlerini belirlemek amacı ile Aikenhead, Ryan ve Fleming (1989) tarafından geliştirilen 114 çoktan seçmeli sorudan oluşan "Bilimin Doğası Hakkındaki Görüşler" (VOSTS) anketinin içinden Doğan Bora tarafından 2005 yılında Türkçe'ye çevrilmiş ve adapte edilmiş olan 25 maddelik VOSTS (TR) anketi kullanılmıştır. Anketin tüm sorularının genel olarak yorumlanması üç kategorinin frekans ve yüzdelik analizleri kullanılarak yapılmıştır. Araştırma soncunda; öğretmen adaylarının toplumun bilim üzerine etkisi, bilimin toplum üzerine etkisi, bilim insanının karakteristik özellikleri, gözlemlerin doğası, sınıflama düzenin doğası, bilimsel bilginin geçiciliği ve değişebilirliği hakkında gerçekçi görüşlere sahip oldukları görülürken, bilimsel buluşlarla cinsiyetin ilişkisi, bilimsel modellerin doğası, hipotez-teori-kanun arasındaki ilişki ve bilimsel bilginin epistemolojik durumu hakkında yetersiz görüşlere sahip oldukları belirlenmiştir.

Anahtar Sözcük: Bilimin doğası, Bilimsel bilgi, Fen Bilgisi Öğretmeni Adayı, Sınıf Öğretmeni Adayı

\section{Abstract}

The aim of this study is to determine the views of preservice science teachers and elementary school pre-service teachers about the nature of science. The study,

* Doç. Dr., Adnan Menderes Üniversitesi, Eğitim Fakültesi, e-posta: nyenice@gmail.com

** Doktora Öğrencisi, Adnan Menderes Üniversitesi, Eğitim Fakültesi, e-posta: barisozdn@gmail.com

${ }^{* * *}$ Fen Bilimleri Öğretmeni, e-posta: cydbalci@gmail.com 
performed in survey model, group of the research has consisted of 142 preservice teachers' who study from class 4. and 1. department of science and classroom teaching. The questionnaire of "Views about the Nature of Science" (VOSTS) which consisted of nine categories and 114 multiple choice questions was developed by Aikenhead, Ryan and Fleming (1989) in an experimental way and 25-item VOSTS (TR) questionnaire which was translated and adapted to Turkish by Doğan Bora was used with the aim of determining the views of the participants. The interpretation of all of the survey questions was performed using frequency and percentage analysis of the three categories. As a result of research; it was determined that the participants had realistic views about; the effect of society on science, the effect of the science on society, characteristics of scientists, the nature of the observations, nature of the classification scheme, impermanence and changeability of knowledge on the other hand they had insufficient views about; the relation of the sex about scientific inventions, the nature of the scientific models, the relation between hypothesis- theory- law and epistemological status of the scientific knowledge.

Keywords: Nature of science, Scientific knowledge, Preservice science teachers, elementary school preservice teachers.

\section{Giriş}

Son yıllarda bilim ve bilimsel bilgi sürekli artmakta ve teknolojik gelişmelerin etkileri yaşamımızın her alanında hissedilmektedir. Dolayısıyla, içinde bulunduğumuz bilgi çă̆ında gelişmiş ve gelişmekte olan toplumlar, bilimi ve bu bilimin oluşturduğu bilimsel bilgiyi doğru anlayan ve kullanabilen bireylere ihtiyaç duymaktadırlar. $\mathrm{Bu}$ nedenle, günümüzde toplumların ihtiyaçları doğrultusunda yenilenen ve geliştirilen eğitim politikaları, öğrencilerin bilim ve teknoloji konusunda yüksek yüzeyde farkındalığa sahip bireyler olarak yetiştirilmesi üzerine yapılandırılmaktadır. (MEB, 2005; MEB, 2013; Saraç, 2012).

Amerikan Bilimi Geliştirme Derneği (AAAS) 1989’da yayımladığ 1 ilk belge olan "Tüm Amerikalılar için Bilim" ile "Bilim okuryazarlığının" geniş bir tanımına yer vermiştir (AAAS, 1993). Bu yıldan sonra bilim okuryazarlığı kavramı özelleştirilerek alanlara yayılmaya başlamıştır. Bu alanlardan biri de fen eğitimidir. Toplumlar sözü edilen becerilere sahip bireyler yetiştirmek için fen bilgisi öğretim programlarında değişikliğe giderek, programlarının vizyonu olarak "Fen okuryazarı bireyler yetiştirmeyi" belirlemişlerdir. Ülkemizde de 2013 yılında öğretim programlarında yapılan değişiklikle "Fen ve Teknoloji” dersinin adı "Fen Bilimleri" olarak değiştirilmiş ve Fen Bilimleri Dersi Öğretim Programının vizyonu; 
"Tüm öğrencileri fen okuryazarı bireyler olarak yetiştirmek" olarak tanımlanmıştır (MEB, 2013).

Fen okuryazarı birey; bilimsel bilgiyi kullanabilen, sosyal ve bireysel amaçlı bilimsel düşünme yollarına başvurabilen kişi olarak tanımlanmaktadır (Sadler, 2004). Abd-El-Khalick, Bell ve Lederman' a (1998) göre ise fen okuryazarı birey, fen ve teknoloji bağlamında bilimsel bilgi, kavram, yasa ve süreçleri kullanarak bilinçli kararlar verebilen kişi olarak tanımlanmıştır. Fen eğitimcilerinin çoğu bireylerin fen okuryazarı olmasının 21. yüzyılda pek çok ekonomik, sosyal ve çevresel sorunlara çözüm getireceğine inanmakta (Moss, Abrams ve Robb, 2001) ve fen okuryazarı birey sayısını artırmak için bilimin doğasının öğretilmesi gerektiğini savunmaktadırlar (Hand, Lawrence ve Yore, 1999). Bu nedenle ilkokul ve ortaokul düzeyinde öğrencilere bilimin doğasının kazandırılması bir gereklilik olarak karşımıza çıkmaktadır.

Bilimsel bilginin değişimine ve gelişimine bağlı olarak, bilimin doğasının kapsadığı kavramların da sürekli gelişim ve değişim gösterdiği görülmektedir. Bu nedenle bilim felsefecileri, tarihçileri ve eğitimcileri bilimin doğası ile ilgili ortak bir tanım yapma konusunda görüş birliğine varamamaktadırlar (Abd-El Khalick ve Lederman, 2000; Çepni, Ayvacı, Bacanak, 2006). Ancak, bilimin doğas1 genellikle bilimin epistemolojisine vurgu yaparak, "Bilim, bilimsel bilgi ve bilimsel bilginin oluşturulma sürecinin özünde var olan değer ve inanışlar" olarak tanımlanmaktadır (Abd-El-Khalick, Bell ve Lederman, 1998; Lederman, 1992; Lederman, 2007).

Bilimin doğasının tanımı hakkında araştırmacılar ve eğitimciler ortak bir karara varamasalar da, öğretmen ve öğrencilerin bilimin doğasının hangi yönlerini bilmesi konusunda görüş birliğine varmışlar ve bireylerin başarabilecekleri seviyede bazı unsurlar ileri sürmüşlerdir (Abd-El-Khalick ve ark., 1998; Altındağ, 2010). Bu unsurlar; bilimsel bilginin kesin olmadığı (değişime maruz olduğu); deneylere dayalı olduğu (doğal dünyanın gözlenmesiyle ortaya çıktığı ve/veya onlara dayalı olduğu); öznel olduğu (bilim insanlarının geçmiş yaşantılarından, deneyimlerinden ve önyargılarından etkilendiği); kısmen insan hayâl gücünün ve yaratıcılığının bir ürünü olduğu (açıklamaların icat edilmesini içerdiği); sosyal ve kültürel 
olarak kurulduğu; gözlem ve çıkarım arasındaki fark; bilimsel teori ve yasa arasındaki ilişki olarak belirtilmiştir.

Bilimin doğasının öğrencilere öğretilmesi uzun zamandan beri fen eğitimcilerinin ortak bir amacıdır (Abd-El-Khalick ve ark., 1998; Driver, Leach, Millar ve Scott, 1996; Hogan, 2000; Lederman, 1992; Reif ve Larkin, 1991). Bu amacı gerçekleştirecek kişiler ise “Öğretmen” lerdir. Wong (2002), fen branşı öğretmenlerinin görevini; öğrencilerin bilimin ve bilimsel bilginin özelliklerini doğru bir şekilde öğrenmelerine rehberlik etmek olmalıdır şeklinde ifade etmiştir (Akt: Doğan Bora, 2005). Bu rehberlik sürecinde öğretmenler gereken bilim ve teknolojiyi kullanma bilgisini ve bunun toplumla ilişkisini öğrencilerine aktarabilirlerse, öğrencilerin bilimsel düşünme yeteneklerinin gelişmesine katkıda bulunabilirler (Zeidler, Walker, Ackett, Simmons, 2002). Benzer şekilde, bilimin doğasıyla ilgili kavramların oluşumunda da, öğrencilerin öğrendikleri bilgiler ile günlük hayat arasında ilişsi kurabilmelerinde de öğretmenlere önemli bir görev düşmektedir (Özcan, 2011). Ancak öğrencilerin bilimsel düşünme yeteneğini kazanabilmesi, bilimin doğası ve bilimsel bilginin özelliklerini özümsemesi bilimin doğasını iyi bilen öğretmenler tarafından gerçekleştirilebilir (Çepni ve ark., 2006; Küçük, 2006). Bu nedenle, ilkokul ve ortaokul öğrencileri için fen eğitiminde anahtar rol oynayan fen bilgisi ve sınıf öğretmeni adaylarının bilimin doğasını anlayan ve bilimsel bilginin özelliklerini özümseyen bireyler olmaları gerekmektedir.

Bilimin doğası ile ilgili hem yurt içinde hem de yurt dışında yapılan çalışmalar incelendiğinde öğrencilerin, öğretmen adaylarının ve öğretmenlerin bilimin doğasına yönelik görüşlerinin araştırıldığ çalışmaların olduğu görülmektedir. Ancak bu çalışmaların çoğunda öğrencilerin, öğretmen adaylarının ve öğretmenlerin bilimin doğasına yönelik görüşlerinin yetersiz ya da yanlış olduğu sonucuna ulaşılmıştır (Abd-El-Khalick ve ark., 2000; Aikenhead, 1987; Altındağ, 2010; Ar1, 2010; Aslan, Yalçın ve Taşar, 2009; Bell, Lederman ve Abd-ElKhalick, 2000; Briscoe, 1991; Çakır, 2012; Demirbaş, Bozdoğan ve Özbek, 2012; Doğan Bora, 2005; Elby ve Hammer, 2001; Erdoğan, 2004; Gürses, Doğar ve Yalçın, 2005; Kahyaoğlu, 2004; Küçük, 2006; Lederman, 1992; Liu ve Lederman, 2007; Macaroğlu, Baysal ve Şahin, 1999; Murcia ve Schibeci, 1999; Niaz, 2009; Özbudak, 2010; 
Palmquist ve Finley, 1997; Şahin, Deniz ve Görgen, 2006; Tatar, Karakuyu ve Tüysüz, 2011; Yalvaç ve Crawford, 2002; Yenice ve Saydam, 2010). Abd- El Khalick (2001), sınıf öğretmenlerinin bilimin doğası ile ilgili görüşlerini incelediği çalışmasında öğretmenlerin bilimsel yöntem, bilimin deneysel doğası ve bilim insanlarının sahip oldukları inançlar gibi konularda geleneksel görüşlere sahip olduklarını tespit etmiştir. Saraç (2012) çalışmasında, sınıf öğretmeni ve öğretmen adaylarının toplumun bilim üzerine etkisi, bilimin toplum üzerine etkisi, gözlemlerin doğası, sınıflama düzeninin doğası, bilimsel bilginin geçiciliği ve değişebilirliği hakkında gerçekçi görüşlere sahip oldukları görülürken, bilimsel buluşlarla cinsiyetin ilişkisi, bilimsel modellerin doğası, hipotez-teori-kanun arasındaki ilişki ve bilimsel bilginin epistemolojik durumu hakkında yetersiz görüşlere sahip oldukları sonucuna ulaşmıştır. Yalçın, Kahraman, Açışlı ve Yılmaz (2010), çalışmalarında fen bilgisi öğretmen adaylarının çoğunun bilimin doğası konusunda çağdaş bakış açısına ve teori - kanun konusunda yaygın kavram yanılgılarına sahip olduklarını belirlemişlerdir. İlgili literatür detaylı bir şekilde incelendiğinde, çalışmaların büyük bir bölümünün ortaokul ve lise öğrencileri, fen bilgisi öğretmenleri ve öğretmen adayları üzerine odaklandığı görülmektedir. Sınıf öğretmenleri ve öğretmen adayları ile ilgili çalışmaların sayısı oldukça azdır (Çakır, 2012; Gürses ve ark., 2005; Saraç, 2012; Tatar ve ark., 2011; Yalçın ve Yalçın, 2011). Aynı zamanda ülkemizde fen bilgisi ve sınıf öğretmeni adaylarının bilimin doğasına yönelik görüşlerinin karşılaştırılarak incelendiği sınırlı sayıda çalışmaya rastlanılmıştır (Arı, 2010).

Öğrencileri bilim ve bilimsel olaylar ile ilgili konularla tanıştıran sınıf öğretmenlerine çok büyük iş düştüğ̈̈; ilerleyen yıllarda ise bu işi fen bilgisi öğretmenlerinin devraldığı düşünüldüğünde, her iki grup öğretmen adaylarının, bilimin doğası konusundaki görüşlerinin tespit edilmesini konu alan çalışmaların yapılması bir gereklilik olarak karşımıza çıkmaktadır. Dolayısıyla, bu çalışmanın amacı fen bilgisi ve sınıf öğretmeni adaylarının bilimin doğasına yönelik görüşlerini tespit etmek ve öğretmen adaylarının bilimin doğasına yönelik görüşlerini öğrenim görülen anabilim dalı değişkeni açısından incelemek olarak belirlenmiştir. $\mathrm{Bu}$ amaçtan hareketle, araştırmanın problem cümlesi "Fen bilgisi ve sınıf öğretmeni 
adaylarının bilimin doğası hakkında görüşleri nelerdir?” şeklinde ifade edilmiştir.

\section{Yöntem}

\section{Araştırma Modeli}

$\mathrm{Bu}$ çalışma, fen bilgisi ve sınıf öğretmeni adaylarının bilimin doğası hakkındaki görüşlerini betimlemeyi amaçlayan bir tarama çalışmasıdır. Tarama modelleri, geçmişte ve günümüzde var olan bir durumu olduğu şekliyle betimlemeyi amaçlayan araştırma yaklaşımlarıdır. Araştırmaya konu olan olay birey ya da nesne, kendi koşulları içinde ve olduğu gibi tanımlanmaya çalışılır (Karasar, 2007).

\section{Çalışma Grubu}

Tarama modelinde gerçekleştirilen araştırmanın çalışma grubunu Adnan Menderes Üniversitesi Eğitim Fakültesi İlköğretim Bölümü Fen Bilgisi ve Sınıf Öğretmenliği Anabilim Dallarının 1. ve 4. sınıflarında öğrenim görmekte olan 142 öğretmen adayı oluşturmuştur. Çalışma grubuna katılan öğretmen adaylarının 76's1 (\%53.5) Fen bilgisi öğretmeni, 66's1 (\% 46.5) sınıf öğretmeni adayıdır. Katılımcıların 106'sı (\% 74.6) k1z, 36's1 (\% 25.4) ise erkek öğretmen adayıdır.

\section{Veri Toplama Aract}

Öğretmen adaylarının "bilimin doğası" hakkındaki görüşlerini belirlemek için Aikenhead, Ryan ve Fleming (1989) tarafindan deneysel yolla geliştirilen 114 çoktan seçmeli sorudan oluşan 'Fen'in Doğası Hakkındaki Görüşler" VOSTS anketi kullanılmıştır. Bu anket sayesinde araştırmacılar, katılımcıların VOSTS anketindeki sorulara verdikleri paragraf cevaplarını okuyarak bilim ve teknoloji konularındaki fikirlerini öğrenebilmektedirler. $\mathrm{Bu}$ nedenle bu araştırmada "Fen'in Doğası Hakkındaki Görüşler" anketinin kullanılmasına karar verilmiştir. Anket; "Bilim ve Teknoloji, Toplumun Bilim ve Teknoloji Üzerine Etkisi, Bilim ve Teknolojinin Toplum Üzerine Etkisi, Bilim İnsanının Karakteristik Özellikleri, Bilimsel Bilginin Sosyal Yapısı, Teknolojinin Sosyal Yapısı, Bilimsel 
Bilginin Doğası" olmak üzere 8 kategoriden oluşmaktadır. Ölçeğin Türkiye için geçerlik ve güvenirlik analizi Doğan Bora (2005) tarafından gerçekleştirilmiştir. Yapılan analizler sonucunda ölçekteki madde sayısı $25^{\prime}$ 'e indirgenmiş ve testin iç tutarlılı̆̆ .72 olarak bulunmuştur. Aynı zamanda anketteki soruların içerik geçerliliği ile ilgili 4 uzmanın görüşleri alınmıştır (Doğan Bora, 2005). Bu çalışma için yapılan güvenirlik analizi sonucunda, testin iç tutarlılık katsayısı .70 olarak tespit edilmiştir.

Araştırmada kullanılan VOSTS (TR) anketinden seçilen 25 sorunun konu başlıkları ve soru dağılımı; Bilimin Tanımı (1 soru), Toplumun Bilim ve Teknoloji Üzerine Etkisi (2 soru), Bilim ve Teknolojinin Toplum Üzerine Etkisi (3 soru), Bilim İnsanının Karakteristik Özelliği (3 soru), Bilimsel Bilginin Sosyal Yapısı (2 soru) ve Bilimsel Bilginin Karakteristik Özellikleri (14 soru) şeklindedir.

\section{Verilerin analizi}

VOSTS (TR) anketinden elde edilen tüm istatistiksel veriler "SPSS 20.0 for Windows" paket programı ile analiz edilmiştir. VOSTS (TR) ölçme aracına verilen yanıtlar, "Gerçekçi”, "Kabul Edilebilir" ve "Yetersiz" olacak şekilde sınıflandırılmıştır (Rubba, Bradford ve Harkness, 1996). Anketin tüm sorularının genel olarak yorumlanması üç kategorinin frekans ve yüzdelik analizleri kullanılarak yapılmıştır. Buna göre Gerçekçi bakış açısı; bilimin doğasına en uygun çağdaş bakış açısını, Kabul Edilebilir durum; gerçekçi bakış açısı göstermemesine rağmen bilimin doğasına uygun, makul bakış açısını ve Yetersiz bakış açısı ise; bilimin doğasına uygun olmayan, yetersiz, zayıf bakış açısını göstermektedir.

Öğrenim görülen anabilim dalı değişkeni ile VOSTS (TR) anketinden elde edilen verileri karşılaştırmada ise Ki-Kare testi kullanılmıştır. Ki-Kare testi parametrik olmayan istatistiklerde kategorik bir değişkenin düzeylerine giren birey ya da nesnelerin anlamlı bir farklılık gösterip göstermediğini test eder (Büyüköztürk, 2010). 


\section{Bulgular}

\section{Bilimin Tanımı}

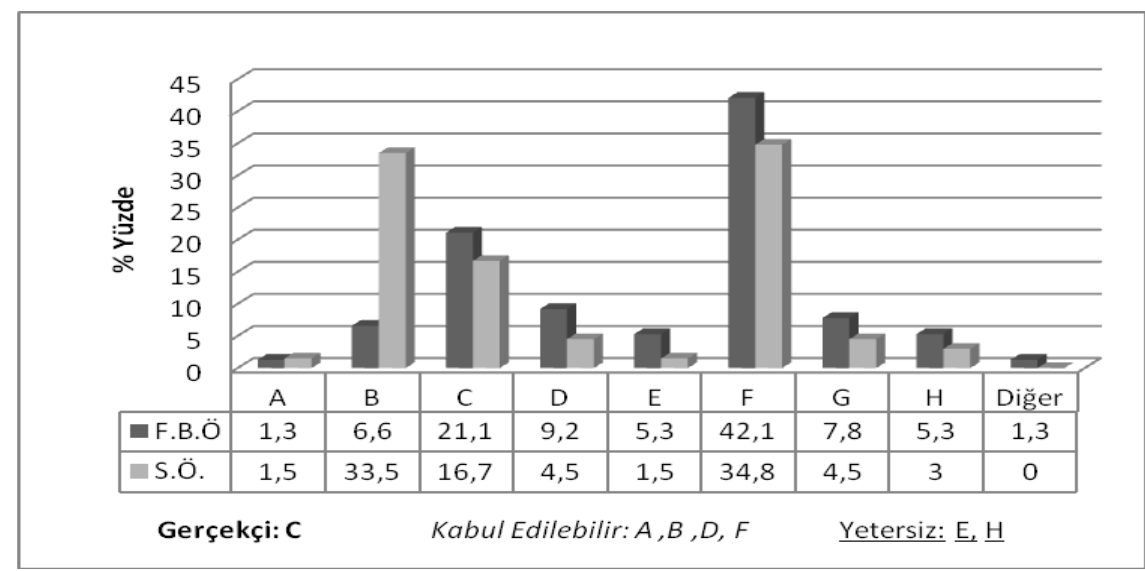

Şekil 1. Fen Bilgisi ve Sınıf Öğretmeni Adaylarının Bilimin Tanımı Sorusuna Verdikleri Cevapların Yüzdesi

Fen bilgisi ve sınıf öğretmeni adaylarının bilimi nasıl tanımladıkları ile ilgili ilk soruya verdikleri cevaplar, adayların bilimin epistemolojisi hakkında ne düşündüklerini gösterecektir (Ryan ve Aikenhead, 1992). Cevaplar incelendiğinde, fen bilgisi ve sinıf öğretmeni adaylarının bilimin tanımı konusunda çeşitli seçenekleri işaretlemelerine rağmen, Kabul Edilebilir bakış açısına sahip oldukları görülmektedir. Gerçekçi bakış açısını gösteren $\mathrm{C}$ seçeneğini fen bilgisi öğretmen adaylarının \% 21.1'i, sınıf öğretmeni adaylarının da \% 16.7'si işaretlemişlerdir. Buradan hareketle, fen bilgisi öğretmen adaylarının sınıf öğretmeni adaylarına göre daha gerçekçi bir bakış açısına sahip olduğu söylenebilir. Bilimin tanımı için Kabul Edilebilir bakış açılarını gösteren A, B, D, F ve G seçenekleri içinde fen bilgisi öğretmen adayları \% 42.1 ve sınıf öğretmeni adayları \% 34.8 oranında en çok $F$ seçeneğini işaretlemişlerdir. Bilimin tanımındaki Yetersiz olan bilimin tanımının yapılamaması (H seçeneği) ve bilimin tanımının teknolojiyle karıştığ 1 , bilimi bir araç olarak gören (E seçeneği) seçeneklerini, fen bilgisi öğretmen adaylarının \% 10.6's1, sınıf öğretmeni adaylarının ise \% 4.5'i işaretlemişlerdir. 
Fen bilgisi ve sınıf öğretmeni adaylarının bilimin tanımı üzerine belirttikleri görüşler arasında anlamlı bir farklılık olup olmadığını belirlemek için ki-kare testi yapılmış ve anlamlı bir farklılık olmadığı tespit edilmiştir $\left(\mathrm{X}_{2}=3.522 ; \mathrm{p}>.05\right)$.

\section{Toplumun Bilim üzerine Etkisi (Etik)}

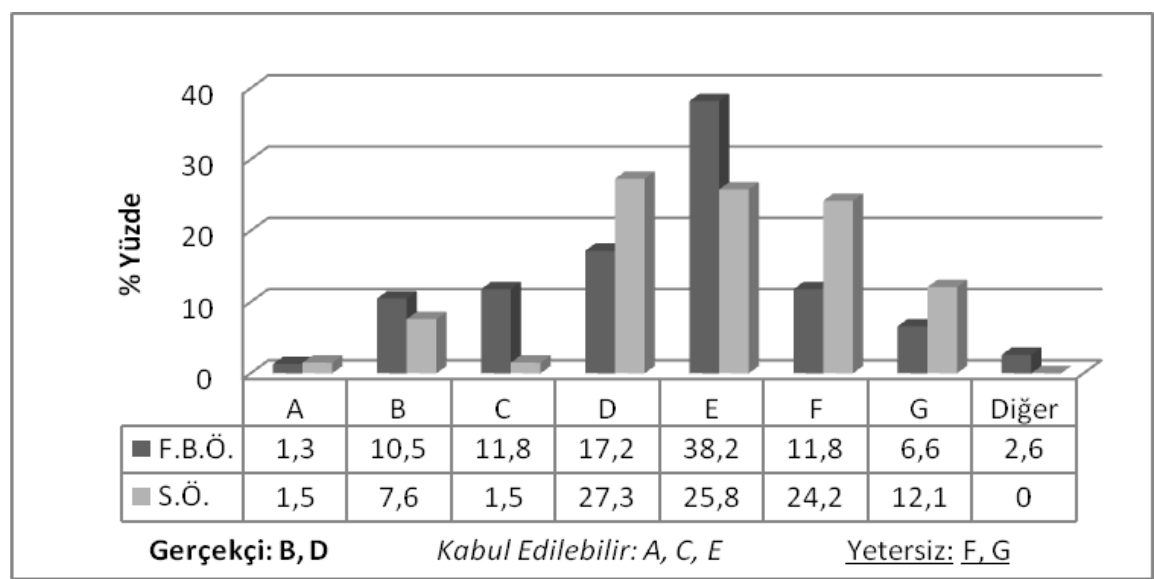

Şekil 2. Fen Bilgisi ve Sınıf Öğretmeni Adaylarının Toplumun Bilim Üzerine Etkisi Sorusuna Verdikleri Cevapların Yüzdesi

Bilimsel araştırmaların yapıldığı yerdeki toplumun kültüründen, dini ve ahlaki görüşünden etkilenip etkilenmediği hakkındaki görüşleri araştıran ikinci madde için fen bilgisi öğretmeni adayları bilimin ortaklaşa ve toplumbilim olarak yapıldığını söyleyen $A, B, C$, $\mathrm{D}, \mathrm{E}$ seçenekleri içerisinden en çok "Belirli kültürel inanışı temsil eden güçlü grupların, belirli araştırma projelerini destekleyeceğini ya da engelleyeceğini söyleyen" E seçeneğini işaretlemişlerdir. Sınıf öğretmeni adaylarının ise en çok "Her toplumun kültürünün yapılan araştırmaların türünü etkileyeceğini" belirten D seçeneğini işaretledikleri görülmektedir. Gerçekçi bakış açısını gösteren B ve D seçeneklerini fen bilgisi öğretmen adaylarının \% 27.7'sinin, sınıf öğretmeni adaylarının \% 34.9'unun işaretlediği tespit edilmiştir. Yetersiz görüşlere sahip cevaplar incelendiğinde ise; fen bilgisi öğretmen adaylarının (\% 18.4), sınıf öğretmeni adaylarına (\% 36.3) 
göre daha az oranda yetersiz cevap seçeneklerini işaretledikleri görülmektedir (Şekil 2).

Fen bilgisi ve sınıf öğretmeni adaylarının toplumun bilim üzerideki etkisine yönelik görüşleri arasında anlamlı bir farklılık olup olmadığını belirlemek için ki-kare testi yapılmış ve anlamlı bir farklılık olduğu tespit edilmiştir $\left(\mathrm{X}_{2}=9.192 ; \mathrm{p}<.05\right)$.

Toplumun Bilim Üzerine Etkisi (Halkın bilim insanlart üzerine etkisi)

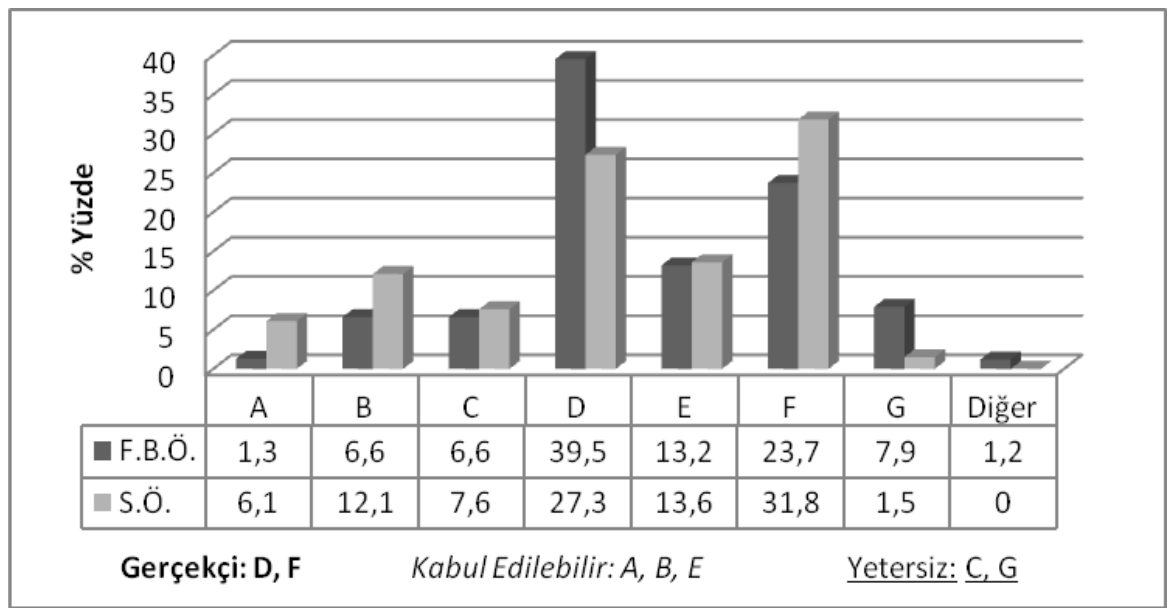

Şekil 3: Fen Bilgisi ve Sınıf Öğretmeni Adaylarının Toplumun Bilim Üzerine Etkisi (Halkın Bilim İnsanları Üzerine Etkisi) Sorusuna Verdikleri Cevapların Yüzdesi

Halkın ve yetiştirme tarzının bilim insanlarını etkilemesi ile ilgili üçüncü madde için Gerçekçi bakış açısını gösteren $\mathrm{D}$ ve $\mathrm{F}$ seçeneklerini fen bilgisi öğretmen adaylarının \% 63.2'si, sınıf öğretmeni adaylarının ise \% 59.1'i işaretlemiştir. Buradan hareketle öğretmen adaylarının bilimi ortaklaşa ve toplumbilim olarak algıladıkları ve fen bilgisi öğretmen adaylarının daha Gerçekçi bir bakış açısına sahip oldukları söylenebilir. Aile yaşantısının, yaşanılan toplumun ve öğretmen rehberliğinin bilim insanlarını etkilemesiyle ilgili $\mathrm{B}, \mathrm{C}, \mathrm{E}, \mathrm{G}$ seçeneklerinin daha az tercih edildiği görülmüştür. Sadece $G$ seçeneğinde fen bilgisi öğretmen adayları (\% 7.9), sınıf öğretmeni adaylarına (\% 1.5) göre yetiştirme tarzının yanı sıra, zekâ, 
yetenek ve bilime olan doğal ilginin daha etkili olduğunu söylemişlerdir (Şekil 3).

Fen bilgisi ve sınıf öğretmeni adaylarının toplumun bilim üzerideki etkisine yönelik görüşleri arasında anlamlı bir farklılık olup olmadığını belirlemek için ki-kare testi yapılmış ve anlamlı bir farklılık olmadığı tespit edilmiştir $\left(\mathrm{X}_{2}=2.513 ; \mathrm{p}>\right.$.05).

Bilimin Toplum Üzerine Etkisi (Bilim insanlarının sosyal

\section{sorumluluğu)}

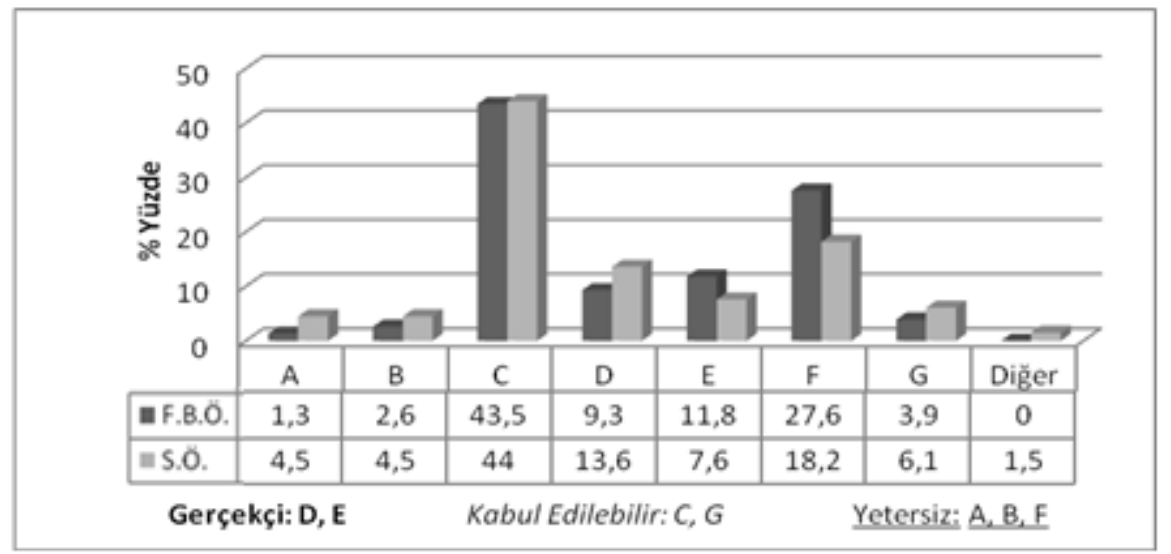

Şekil 4: Fen Bilgisi ve Sınıf Öğretmeni Adaylarının Bilimin Toplum Üzerine Etkisi (Bilim İnsanlarının Sosyal Sorumluluğu) Sorusuna Verdikleri Cevapların Yüzdesi

Anketin 4. sorusu bilim insanlarının buluşlarının olası yararlı ve zararlı yönlerini dikkate alıp almadıklarını içeren değişik ifadelerden oluşmaktadır. Bilim insanlarının deneylerinin bütün sonuçları ile ilgilendiklerini kabul eden $\mathrm{C}$ seçeneği fen bilgisi öğretmen adaylarının $\% \quad 43.5$ 'i ve sınıf öğretmeni adaylarının \% 44'ü tarafından işaretlenerek en çok tercih edilen seçenek olmuştur. Bilim insanlarının buluşlarını gerçekleştirirken, buluşlarının sadece faydalı yönleri ile ilgilendiklerini ve buluşlarının zararlı etkilerini önlemek için daha fazla çalıştıklarını belirten A ve B seçenekleri öğretmen adayları tarafından en az işaretlenen seçenekler olmuştur. Kabul Edilebilir seçeneklerini fen bilgisi öğretmen adaylarının \% 47.3'ü ve sinıf ögretmeni adaylarının \% 50.1'i işaretlemiştir. Bu sonuca göre sınıf 
öğretmeni adaylarının fen bilgisi öğretmen adaylarına göre daha kabul edilebilir yanıtlar verdiği söylenebilir. Ayrıca Yetersiz bakış açısının Gerçekçi seçeneklerin oranına yakın olması dikkat çekici bulgulardan biridir (Şekil 4).

Fen bilgisi ve sınıf öğretmeni adaylarının Bilimin Toplum Üzerine Etkisine yönelik görüşleri arasında anlamlı bir farklılık olup olmadığını belirlemek için ki-kare testi yapılmış ve anlamlı bir farklılık olmadığ

Bilimin Toplum Üzerine Etkisi (Sosyal kararlara katkısı)

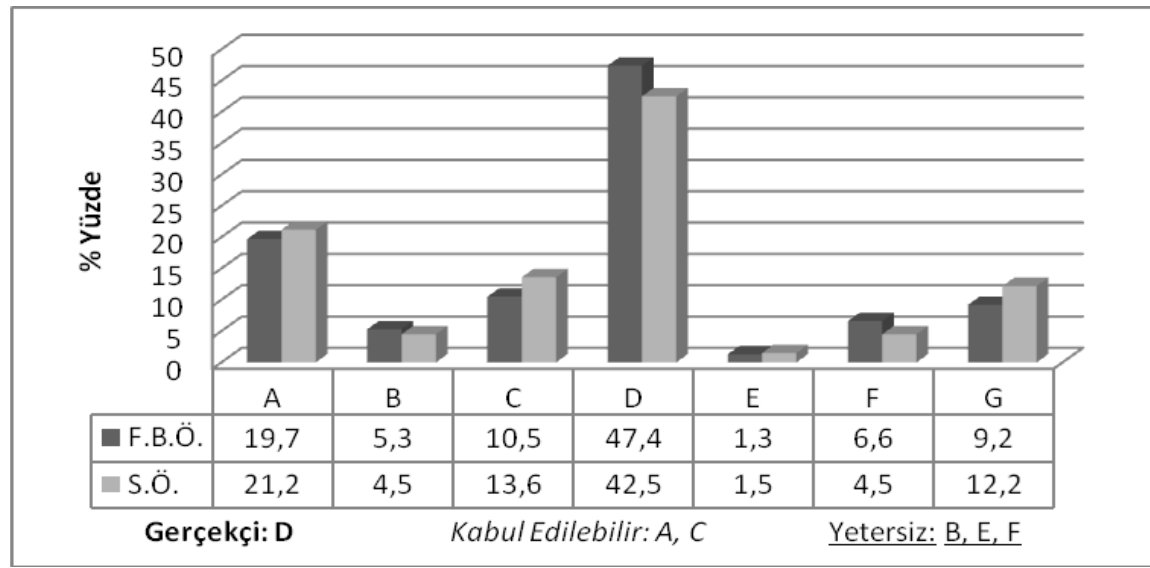

Şekil 5: Fen Bilgisi ve Sınıf Öğretmeni Adaylarının Bilimin Toplum Üzerine Etkisi (Sosyal Kararlara Katkısı) Sorusuna Verdikleri Cevapların Yüzdesi

Genetiği değiştirilmiş organizmalar, insan klonlama ya da genom projesi gibi bilimsel olaylarda karar vericilerin kimler olmasi gerektiğiyle ilgili bakış açılarının bulunduğu beşinci soruda bilimin ortaklaşa ve toplumbilim olarak yapıldığ Gerçekçi görüşü ifade eden $\mathrm{D}$ seçeneği fen bilgisi öğretmen adayları (\% 47.4) tarafından, sınıf öğretmeni adaylarına göre $\left(\begin{array}{l}\% \\ 42.5\end{array}\right)$ daha çok tercih edilmiştir. Buradan hareketle fen bilgisi öğretmen adaylarının sınıf öğretmeni adaylarına göre daha Gerçekçi görüşe sahip oldukları söylenebilir.

Fen bilgisi ve sınıf öğretmeni adaylarının toplumun bilim üzerideki etkisine yönelik görüşleri arasında anlamlı bir farklılık olup 
olmadığını belirlemek için ki-kare testi yapılmış ve anlamlı bir farklılık olmadığı tespit edilmiştir $\left(\mathrm{X}_{2}=.423\right.$; $\mathrm{p}>$.05).

Bilim İnsanının Sosyal ve Pratik Problemlere Çözüm Yeteneği (Bilimin Toplum Üzerine Etkisi)

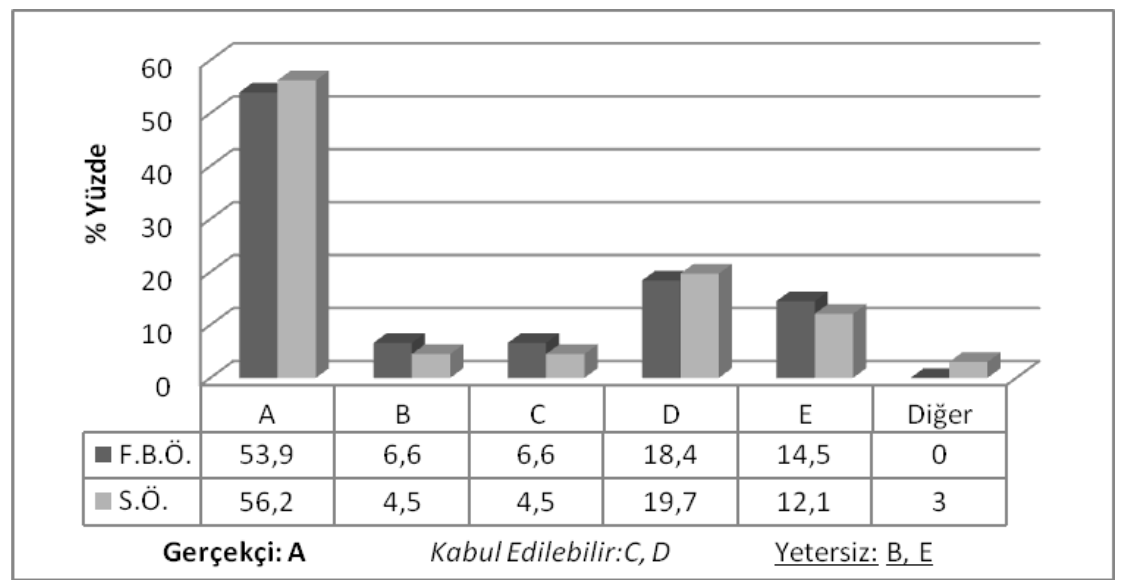

Şekil 6. Fen Bilgisi ve Sınıf Öğretmeni Adaylarının Bilim İnsanının Sosyal ve Pratik Problemlere Çözüm Yeteneği Sorusuna Verdikleri Cevapların Yüzdesi

Bilim insanlarının gündelik problemlerini nasıl çözdügü ile ilgili olan altıncı maddenin, okuldaki fen bilgisi derslerinin öğrencilere problem çözme becerisi kazandırmasıyla ilgili B seçeneğini hem sınıf öğretmen adayları (\% 4.5) hem de fen bilgisi öğretmen adayları (\% 6.6) en az tercih etmişler ve okuldaki fen derslerinin günlük hayatlarında problem çözme becerisi kazandırma konusunda faydalı olmadığını belirtmişlerdir. Fen bilgisi ögretmen adayları (\% 53.9) ile sınıf öğretmeni adayları (\% 56.2) bilim insanlarının diğer insanlardan daha bilgili olduklarını söyleyen Gerçekçi bakış açısını gösteren A seçeneğini diğer seçeneklerden daha fazla tercih etmişlerdir. Kabul Edilebilir bakış açısına fen bilgisi öğretmen adayları ile sınıf öğretmeni adaylarının benzer cevaplar verdiği görülmüştür. Yetersiz bakış açısını içeren seçenekleri ise fen bilgisi öğretmen adaylarının (\% 
21.1), sınıf öğretmeni adaylarına (\% 16.6) göre daha fazla oranda seçtiği tespit edilmiştir.

Fen bilgisi ve sınıf öğretmeni adaylarının bilimin toplum üzerine etkisine yönelik görüşleri arasında anlamlı bir farklılık olup olmadığını belirlemek için ki-kare testi yapılmış ve anlamlı bir farklılık olmadığ 1 tespit edilmiştir $\left(\mathrm{X}_{2}=.362 ; \mathrm{p}>.05\right)$.

\section{Bilim İnsanının Çalışmasına, Yaşantısına Etki Eden Değerleri (Bilim Ínsanının Karakteristik Özellikleri)}

Başarılı bilim insanlarının kişisel özellikleriyle ilgili olan yedinci maddeye verilen cevaplar incelendiğinde, fen bilgisi (\% 48.7) ve sınıf ögretmeni (\% 48.5) adaylarının; bilim insanlarının hayal gücü gibi kişisel özelliklere de sahip olması gerektiğini söyleyen C seçeneğini daha çok işaretlediği görülmektedir. Bilimde başarılı olmak için bu özelliklere gerek olmadığını söyleyen $F$ seçeneğini fen bilgisi $(\% 0.0)$ ve sınıf öğretmeni (\% 3.0) adayları çok az tercih ettiklerinden, öğretmen adaylarının kişisel özelliklerin bilim insanı olmak için gerekli olduğuna inandıkları söylenebilir. Gerçekçi bakış açısına Fen bilgisi (\% 75.0) ve sınıf öğretmeni (\% 68.3) adaylarının yüksek oranlarda sahip olduğu bulunmuştur (Şekil 7).

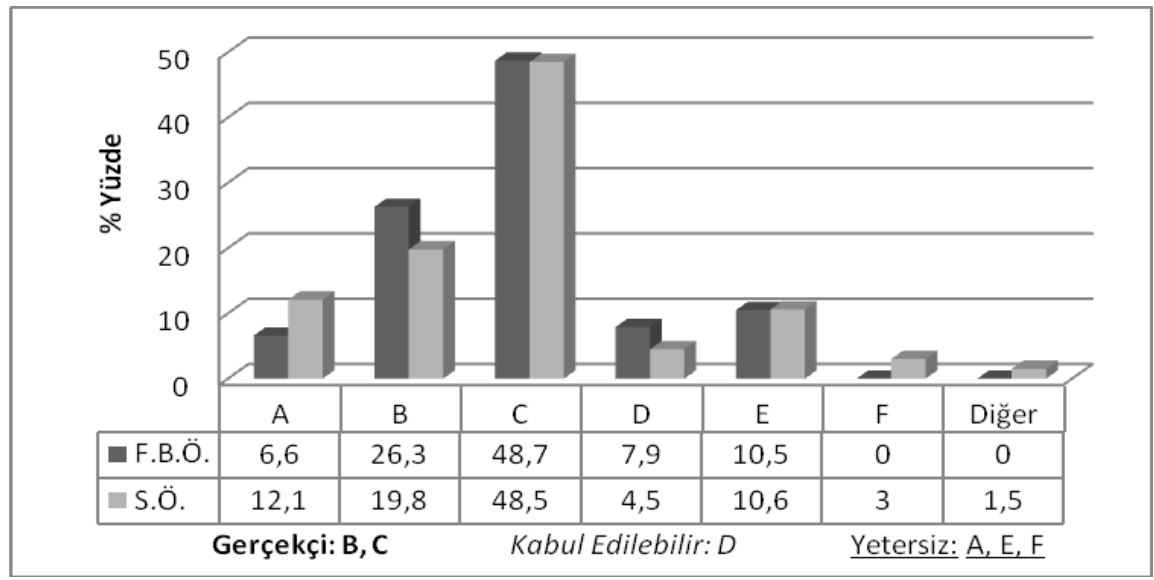

Şekil 7. Fen Bilgisi ve Sınıf Öğretmeni Adaylarının Bilim İnsanının Çalışmasına ve Yaşantısına Etki Eden Değerler Sorusuna Verdikleri Cevapların Yüzdesi 
Fen bilgisi ve sınıf öğretmeni adaylarının bilim insanının karakteristik özelliklerine yönelik görüşleri arasında anlamlı bir farklılık olup olmadığını belirlemek için yapılan ki-kare testi sonuçlarına göre anlamlı bir farklılık olmadığ 1 tespit edilmiştir $\left(\mathrm{X}_{2}\right.$ $=2.100 ; \mathrm{p}>.05)$.

Bilim İnsanının Karakteristik Özellikleri (Bilim yapmak için yetenekleri)

Bilim insanının sosyal yönü ile ilgili olan sekizinci maddeye fen bilgisi ve sınıf öğretmeni adaylarının verdikleri cevaplar incelendiğinde, bilim insanının çalışmalarının farklı ama bunun sosyal hayatları olmadığı anlamına gelmediğini söyleyen $\mathrm{C}$ seçeneğini, fen bilgisi öğretmen adaylarının \% 40.8'inin, sınıf öğretmeni adaylarının \% 27.3'ünün işaretlediği görülmektedir. Yine kişiye bağlı olduğunu söyleyen B seçeneğini fen bilgisi öğretmen adaylarının \% 19.7'si, sınıf öğretmeni adaylarının $\% \quad 34.8$ 'i işaretlemişlerdir. Toplam bulgular incelendiğinde; sınıf öğretmeni adaylarının (\% 62.1), fen bilgisi öğretmen adaylarına (\% 60.5) göre daha fazla Gerçekçi bakış açısına sahip olduğu bulunmuştur (Şekil 8).

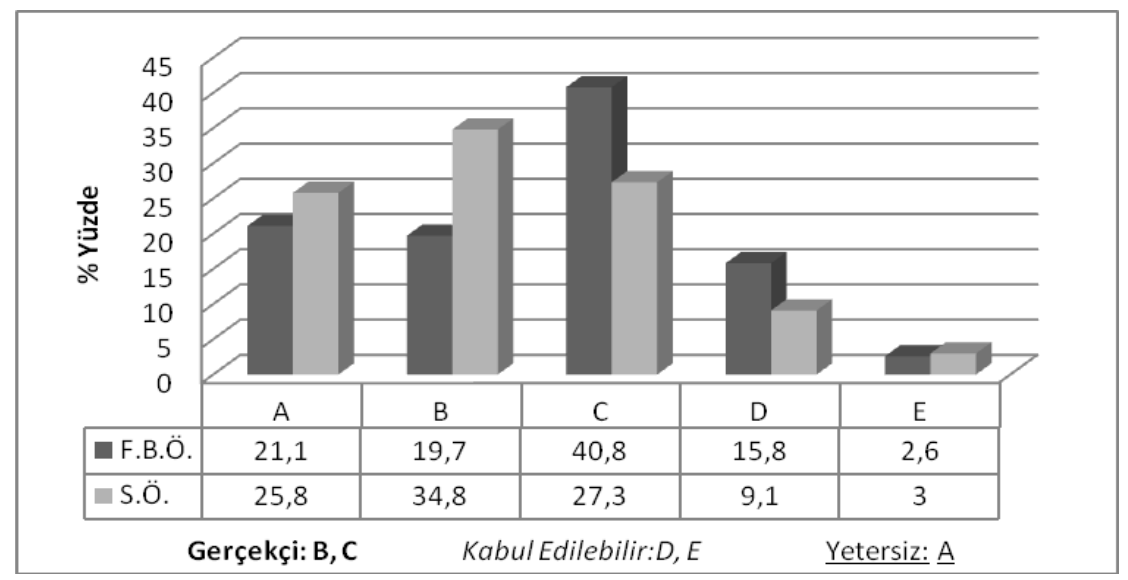

Şekil 8. Fen Bilgisi ve Sınıf Öğretmeni Adaylarının Bilim İnsanının Bilim Yapmak İçin Yetenekleri Sorusuna Verdikleri Cevapların Yüzdesi 
Fen bilgisi ve sınıf öğretmeni adaylarının bilim insanının karakteristik özelliklerine yönelik görüşleri arasında anlamlı bir farklılık olup olmadığını belirlemek amacıyla yapılan ki-kare testi sonuçlarına göre anlamlı bir farklılık olmadığ 1 tespit edilmiştir $\left(\mathrm{X}_{2}\right.$ $=1.256 ; \mathrm{p}>.05)$.

Bilimin Yöntemi ve Üretimi Üzerine Cinsiyetin Etkileri (Bilim Insanının Karakteristik Özellikleri)

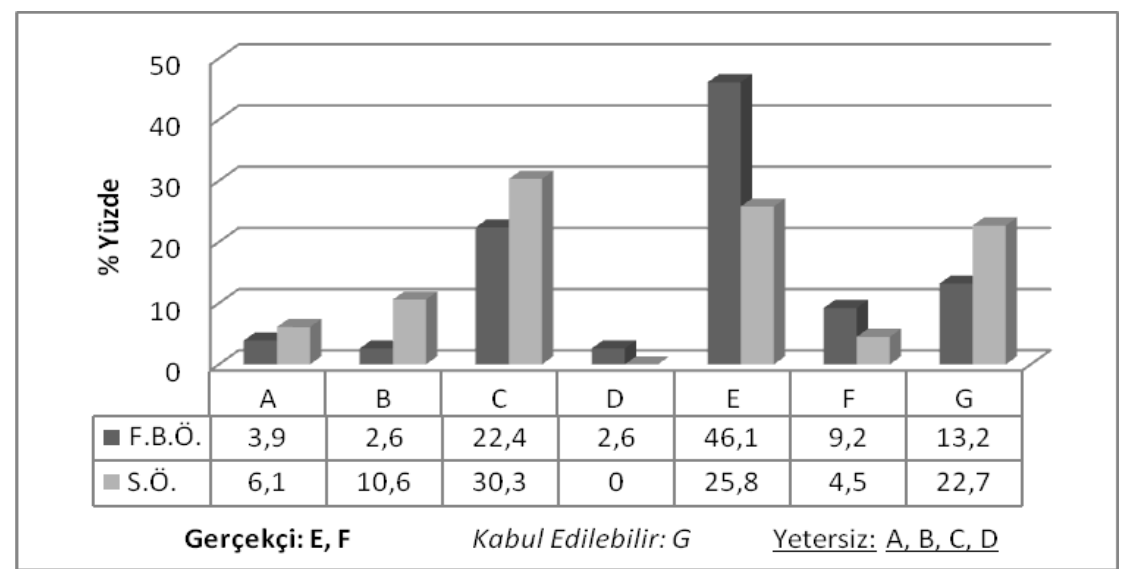

Şekil 9. Fen Bilgisi ve Sınıf Öğretmeni Adaylarının Bilimin Yöntemi ve Üretimi Üzerine Cinsiyetin Etkileri Sorusuna Verdikleri Cevapların Yüzdesi

Bilim insanlarının yaptıkları buluşlarda cinsiyetin fark yaratıp yaratmadığı ile ilgili olan dokuzuncu maddede; kadın ve erkeğin aynı eğitimi aldığı halde kadınlara geçmişten günümüze kadar yeterli olanakların verilmemesinin, onların bilimsel yeteneklerinin ortaya çıkmasına engel olduğunu söyleyen E seçeneğini fen bilgisi öğretmen adaylarının \% 46.1'i, sınıf öğretmeni adaylarının \% 25.8'i tercih etmişlerdir. Doğaları gereği kadınların farklı hafızaya, içgüdüye ve bakış açılarına sahip olduğunu söyleyen $\mathrm{C}$ seçeneğini fen bilgisi öğretmen adaylarının \% 22.4'ü, sınıf öğretmeni adaylarının \% 30.3'ü işaretlemiştir. Fen bilgisi öğretmen adaylarının (\% 55.3), sınıf öğretmeni adaylarına (\% 30.3) göre daha gerçekçi bakış açısına sahip olduğu bulunmuştur. Yetersiz bakış açısına ise; sınıf öğretmeni 
adaylarının (\% 47), fen bilgisi öğretmeni adaylarına (\% 31.5) göre daha fazla sahip olduğu tespit edilmiştir (Şekil 9).

Fen bilgisi ve sınıf öğretmeni adaylarının bilim insanının karakteristik özelliklerine yönelik görüşleri arasında anlamlı bir farklılık olup olmadığını belirlemek için ki-kare testi yapılmış ve anlamlı bir farklılık gösterdiği tespit edilmiştir $\left(\mathrm{X}_{2}=9.038 ; \mathrm{p}<.05\right)$.

Bilimsel Bilginin Sosyal Yapısı (Rekabet karşısında profesyonel etkileşim, politik, gizlilik, aşırma, çalıntı)

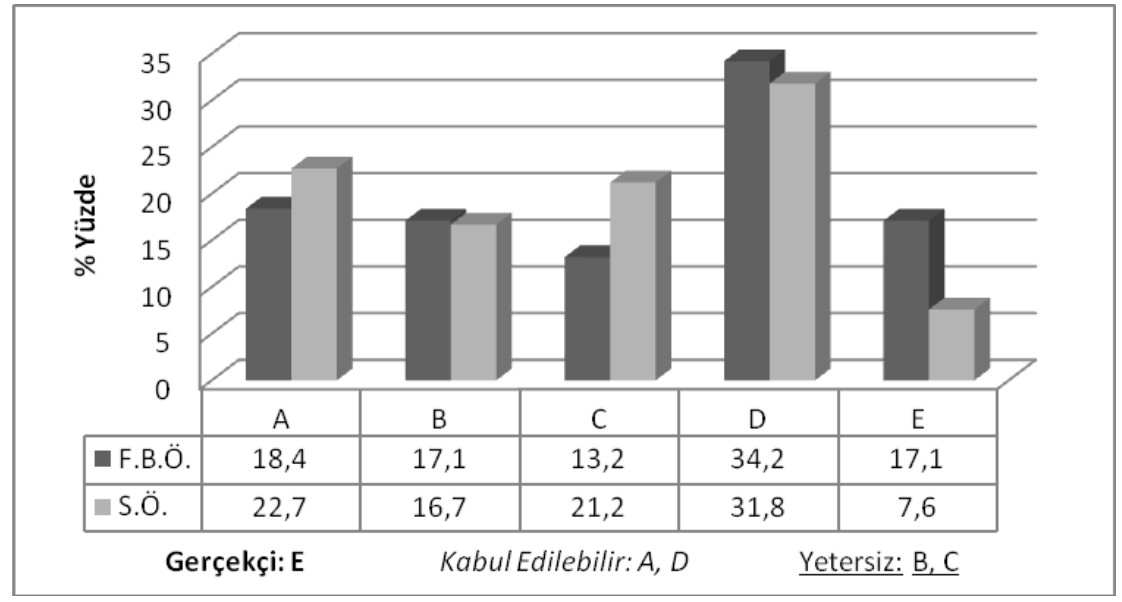

Şekil 10. Fen Bilgisi ve Sınıf Öğretmeni Adaylarının Bilimsel Bilginin Sosyal Yapısı (Rekabet Karşısında Profesyonel Etkileşim, Politik, Gizlilik, Aşırma, Çalıntı) Sorusunda Verdikleri Cevapların Yüzdesi

Anketin 10. sorusu bilim insanlarının bazen paylaşma, dürüstlük ve bağımsızlık gibi bilimin kurallarını çiğneyip çiğnemedikleri ile ilgili ifadelerden oluşmaktadır. Bilimin diğer mesleklerden farklı olmadığını söyleyen D seçeneğini fen bilgisi öğretmen adaylarının \% 34.2'si ve sınıf öğretmeni adaylarının 31.8'si işaretlemişlerdir. Bilim insanları arasında yarış olmadığını, birbirleriyle işbirliği içerisinde çalıştığını söyleyen E seçeneğini fen bilgisi öğretmen adaylarının \% 17.1'i, sınıf ögretmeni adaylarının ise \% 7.6'sının tercih etmesi fen bilgisi öğretmen adaylarının daha Gerçekçi bakış açısına sahip olduğunu göstermiştir. Bilim insanlarının rekabeti ile ilgili olan bu 
soruya sınıf öğretmeni adayları (\% 54.6), fen bilgisi öğretmen adaylarına (\% 52.5) göre daha Kabul Edilebilir cevaplar vermişlerdir (Şekil 10).

Fen bilgisi ve sınıf öğretmeni adaylarının Bilimsel Bilginin Sosyal Yapısına yönelik görüşleri arasında anlamlı bir farklılık olup olmadığını belirlemek için yapılan ki-kare testi sonuçlarına göre anlamlı bir farklılık göstermediği tespit edilmiştir $\left(\mathrm{X}_{2}=3.161 ; \mathrm{p}>.05\right)$.

Bilim İnsanının Sosyal İlişkileri (Bilimsel Bilginin Sosyal Yaptsi)

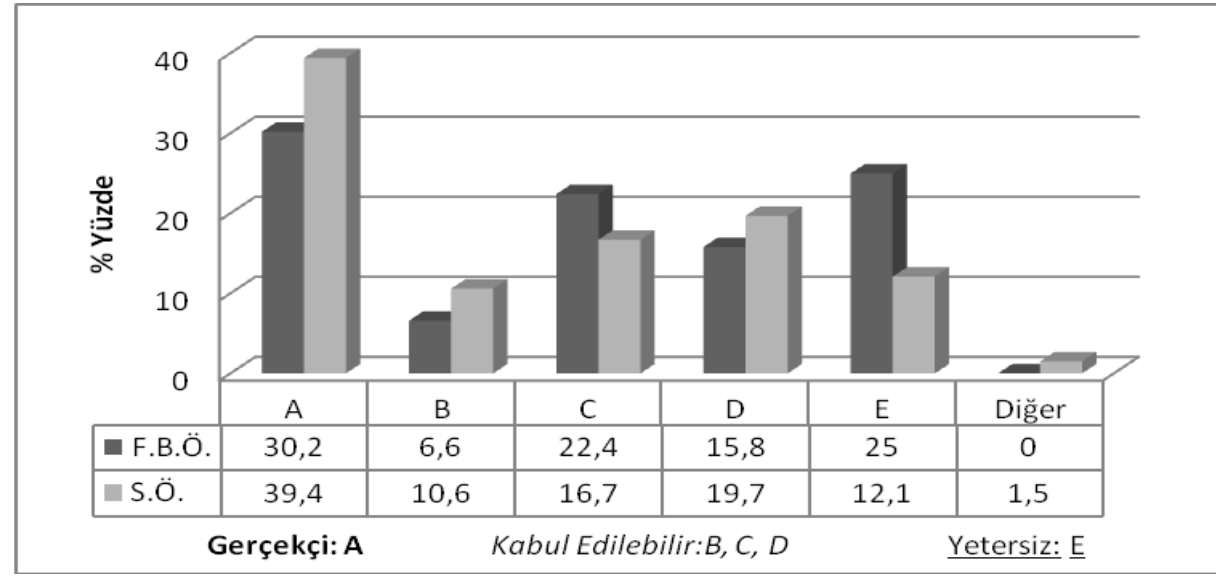

Şekil 11. Fen bilgisi ve sınıf öğretmeni adaylarının Bilim insanının Sosyal ilişkileri (Bilimsel Bilginin Sosyal Yapısı) sorusunda verdikleri cevapların yüzdesi

Bilim insanlarının sosyal ilişkilerinin buluşlarının içeriğini etkileyeceğiyle ya da etkilemeyeceğiyle ilgili ifadelerin bulunduğu 11. soruda, bilim insanlarının etkileşim içinde oldukları insanların fikirlerinden, deneyimlerinden yararlandığını söyleyen Gerçekçi görüşü ifade eden A seçeneği öğretmen adayları tarafından en çok tercih edilen seçenek olmuştur (Fen bilgisi ögretmen adayları \% 30.3, sınıf ögretmeni adayları \% 39.4). Kabul Edilebilir seçenekleri fen bilgisi öğretmen adaylarının \% 47.8'i, sınıf öğretmeni adaylarının \% 47'si tercih ederken, Yetersiz bakış açısına fen bilgisi öğretmen adaylarının, sınıf öğretmeni adaylarından daha fazla sahip olduğu tespit edilmiştir (Şekil 11). 
Fen bilgisi ve sınıf öğretmeni adaylarının bilimsel bilginin sosyal yapısına yönelik görüşleri arasında anlamlı bir farklılık olup olmadığını belirlemek için ki-kare testi yapılmış ve anlamlı bir farklılık göstermediği tespit edilmiştir $\left(\mathrm{X}_{2}=3.970 ; \mathrm{p}>.05\right)$.

\section{Gözlemlerin Doğası (Bilimsel Bilginin Doğası)}

Anketin on ikinci sorusu bilim insanlarının inançlarının yaptıkları gözlemleri etkileyip etkilememesi ile ilgilidir. Bilim insanlarının gözlemlerinin farklı olacağıyla ilgili Gerçekçi görüşü ifade eden A ve B seçenekleri öğretmen adayları tarafindan en çok tercih edilen seçenekler olmuştur. Öğretmen adaylarından fen bilgisi öğretmen adaylarının \% 83'ü, sınıf öğretmeni adaylarının ise \% 83.4'ünün daha gerçekçi bakış açısına sahip oldukları, Yetersiz cevapların ise her iki öğretmen adayları tarafından az oranda (fen bilgisi öğretmen adayları \% 3.9 , sınıf öğretmeni adayları \% 1.5 ) işaretlendiği belirlenmiştir (Şekil 12).

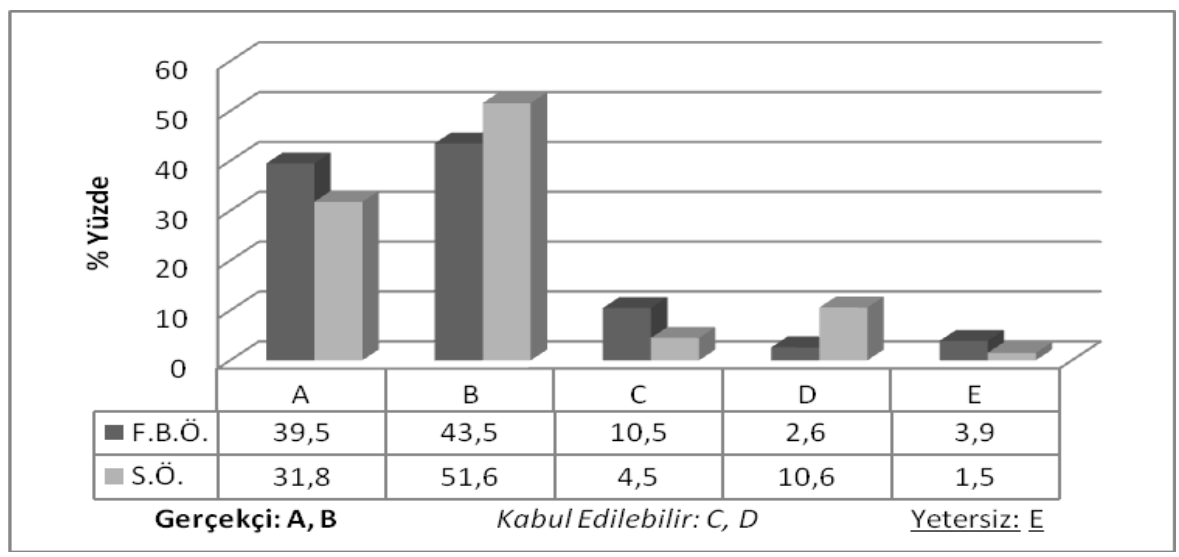

Şekil 12. Fen Bilgisi ve Sınıf Öğretmeni Adaylarının Gözlemlerin Doğası (Bilimsel Bilginin Doğası) Sorusuna Verdikleri Cevapların Yüzdesi

Fen bilgisi ve sınıf öğretmeni adaylarının gözlemlerin doğasına yönelik görüşleri arasında anlamlı bir farklılık olup olmadığını belirlemek için yapılan ki-kare testi sonuçlarına göre anlamlı bir farklılık göstermediği tespit edilmiştir $\left(\mathrm{X}_{2}=.842\right.$; $\left.\mathrm{p}>.05\right)$. 


\section{Bilimsel Modellerin Doğası (Bilimsel Bilginin Doğası)}

Bilimsel modellerin gerçeğin kopyası olup olmadığı ile ilgili iki farklı bakış açısı olan on üçüncü soruda bilimsel modellerin gözlem ve araştırmalara dayandığını söyleyen D seçeneğini fen bilgisi öğretmen adayları \% 17.1, sınıf ögretmeni adayları \% 33.3 oranında tercih etmişlerdir. Bilimsel modellerin gerçek olduğunu söyleyen B seçeneğini sınıf öğretmeni adayları (\% 24.2) fen bilgisi öğretmen adaylarından (\% 21.1) daha fazla işaretlemişlerdir. Bilimsel modellerin düşünce ya da tahminlerden oluştuğunu, dolaylı yoldan hayal gücü ile yaratıcılığın önemini vurgulayan postpositivist bakış açısına uygun $\mathrm{G}$ seçeneği ise fen bilgisi öğretmen adayları (\% 3.9) ve sınıf öğretmeni adayları tarafından $(\%$ 1.5) en az tercih edilmiştir. Bilimsel araştırmalarda ya da teori ve kanunların kavranmasında oldukça önemli yeri olan bilimsel modellerin fen bilgisi öğretmen adayları (\% 65.8) ve sinıf öğretmeni adayları (\% 75.8) tarafından yeterince anlaşılmaması önemli bir tespit olmuştur (Şekil 13).

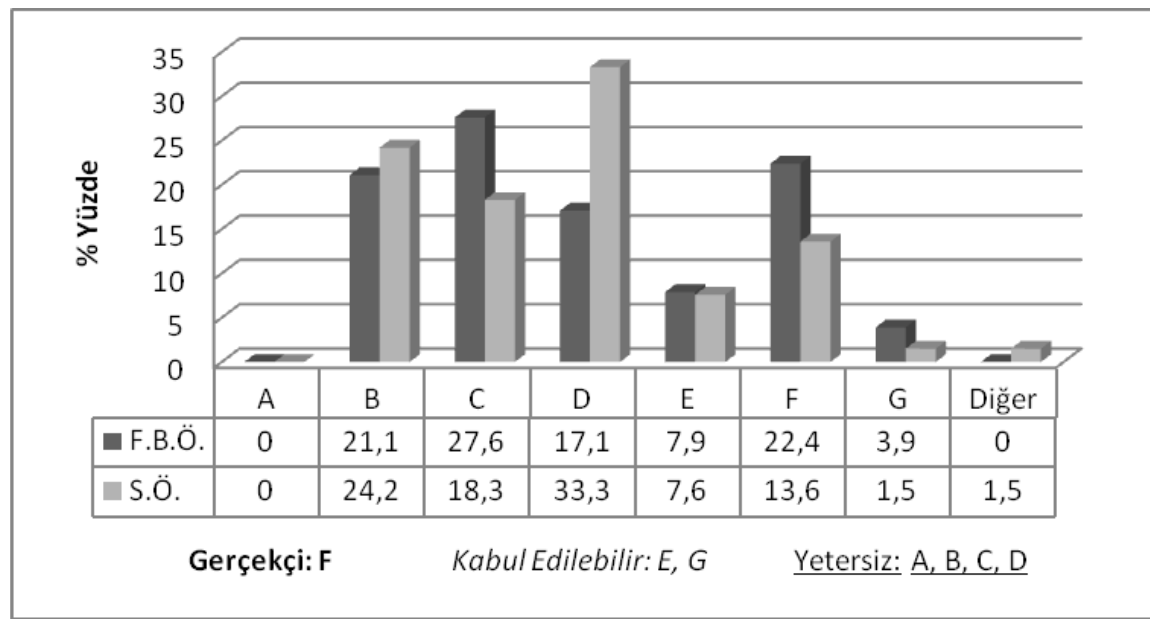

Şekil 13. Fen Bilgisi ve Sınıf Öğretmeni Adaylarının Bilimsel Modellerin Doğası Sorusuna Verdikleri Cevapların Yüzdesi

Fen bilgisi ve sınıf öğretmeni adaylarının bilimsel modellerin doğasına yönelik görüşleri arasında anlamlı bir farklılık olup 
olmadığını belirlemek için ki-kare testi yapılmış ve anlamlı bir farklılık göstermediği tespit edilmiştir $\left(\mathrm{X}_{2}=2.217\right.$; $\mathrm{p}>$.05).

\section{Sınıflama Düzeninin Doğası (Bilimsel Bilginin Doğası)}

Anketin on dördüncü sorusunda sinıflandırmanın bilim insanlarının çalışmalarındaki karışıklıkları önleyeceğini söyleyen D seçeneğini fen bilgisi öğretmen adayları (\% 18.4), sınıf öğretmeni adaylarıyla ( $\%$ 22.7) benzer oranlarda tercih etmişlerdir. Bilim insanlarının sınıflandırmaların doğadaki gerçeklerle birebir uyumlu olduğunu kanıtlayacağını söyleyen A seçeneğini sınıf öğretmeni adayları (\% 21.2), fen bilgisi öğretmen adaylarından (\% 6.6) üç kat fazla işaretlemişlerdir. Bilim insanlarının doğada yaptıkları sınıflandırmalar hakkındaki bakış açılarını ortaya çıkarmayı hedefleyen bu soruda fen bilgisi öğretmen adaylarının (\% 50.0), sınıf öğretmeni adaylarına (\% 40.9) göre daha Gerçekçi bakış açısına sahip olduğu tespit edilmiştir.

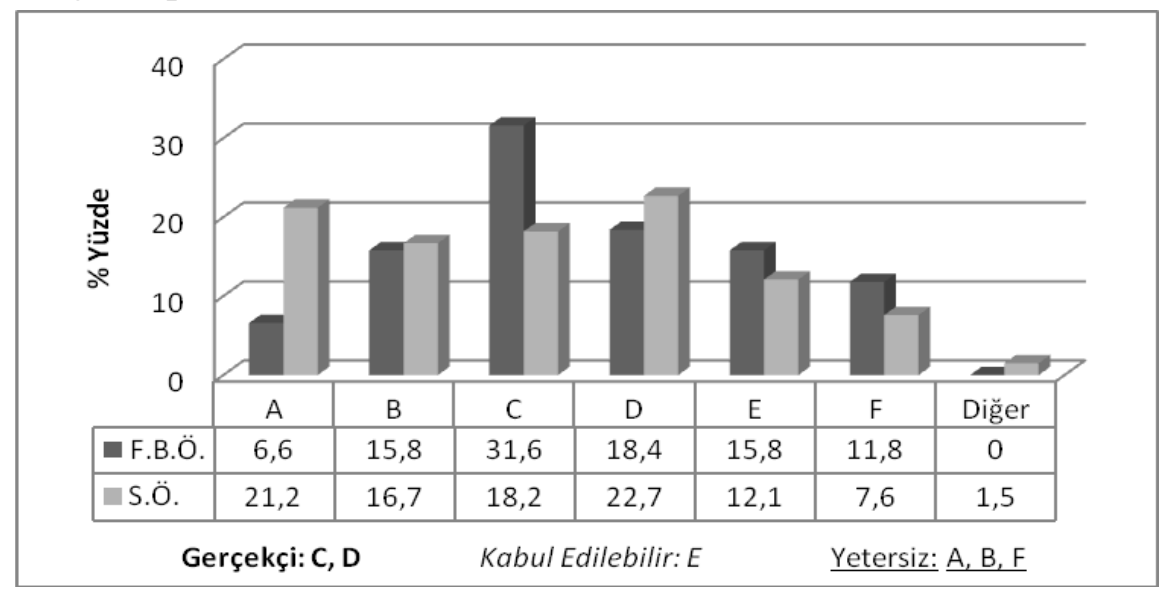

Şekil 14. Fen Bilgisi ve Sınıf Öğretmeni Adaylarının Sınıflama Düzeninin Doğası (Bilimsel Bilginin Doğası) Sorusuna Verdikleri Cevapların Yüzdesi

Fen bilgisi ve sınıf öğretmeni adaylarının sınıflama düzeninin doğasına yönelik görüşleri arasında anlamlı bir farklılık olup olmadığını belirlemek için yapılan ki-kare testi sonuçlarına göre anlamlı bir farklılık göstermediği tespit edilmiştir $\left(\mathrm{X}_{2}=2.102\right.$; $\left.\mathrm{p}>.05\right)$. 
N.Yenice,B.Özden... / Ë̈ Eğitim Fakültesi Dergisi,17(1)(2015), 237-281

\section{Bilimsel Bilginin Geçiciliği (Bilimsel Bilginin Doğası)}

Bilimsel bilginin değişip değişmediği ile ilgili anketin on beşinci maddesine sınıf öğretmeni adayları \% 59.1 ve fen bilgisi öğretmen adayları \% 51.3 oranıyla A seçeneğini işaretleyerek, bilimsel bilginin yeni tekniklerle değişebileceğine inandıklarını söyleyerek Gerçekçi bakış açısına sahip olduklarını göstermişlerdir. Benzer şekilde bilimsel bilgilerin yeniden yorumlanmasıyla değişebileceğini söyleyen B seçeneği fen bilgisi öğretmen adaylarının \% 22.4'ü ve sınıf öğretmeni adaylarının \% 27.4'ü tarafından işaretlenmiştir. Bilimsel bilginin değişebilirliği konusunda fen bilgisi öğretmen adayları (\% 3.9) ve sınıf öğretmeni adaylarının (\% 4.5) benzer oranlarda Kabul Edilebilir bakış açısına sahip olmaları dikkat çekici bir bulgudur (Şekil 15).

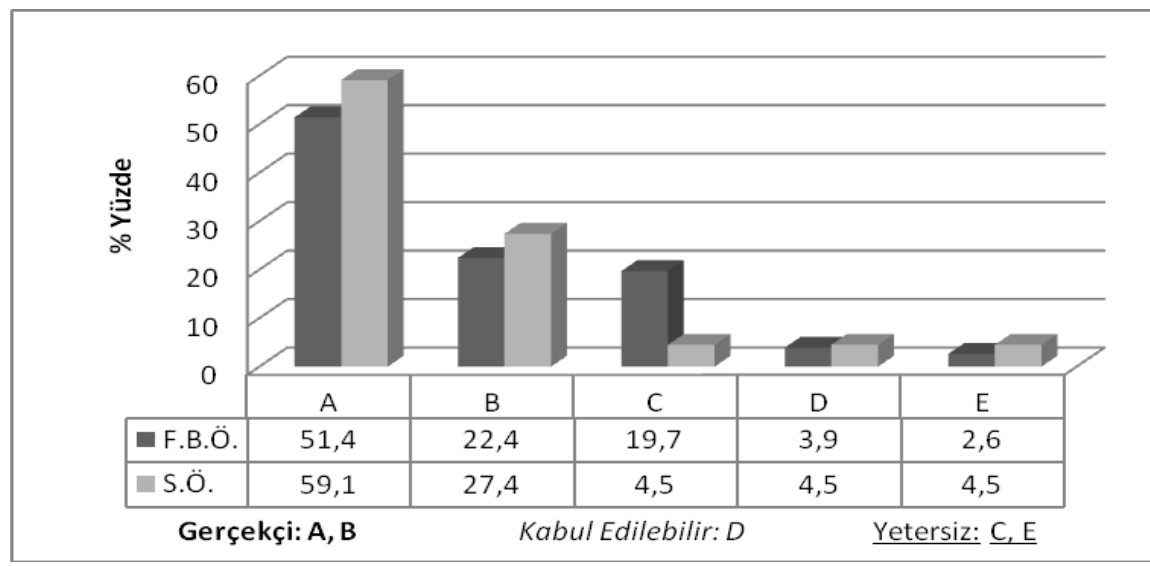

Şekil 15. Fen Bilgisi ve Sınıf Öğretmeni Adaylarının Bilimsel Bilginin Geçiciliği (Bilimsel Bilginin Doğası) Sorusuna Verdikleri Cevapların Yüzdesi

Fen bilgisi ve sınıf öğretmeni adaylarının bilimsel bilginin geçiciliğine yönelik görüşleri arasında anlamlı bir farklılık olup olmadığını belirlemek için yapılan ki-kare testi sonuçlarına göre anlamlı bir farklılık göstermediği tespit edilmiştir $\left(\mathrm{X}_{2}=4,588 ; \mathrm{p}>.05\right)$.

Bilimsel Bilginin Doğası (Hipotezler, teoriler ve kanunlar, tanımı, varsayımların rolü, inançlar) 
Bilimsel düşüncelerin hipotezlerden teorilere doğru geliştiğini, yeterince desteklendiğinde ise kanun olduğunu ifade eden on altınc1 soruda fen bilgisi öğretmen adaylarının (\% 43.4) ve sınıf öğretmeni adaylarının (\% 75.3) büyük bir çoğunluğunun hipotezlerin, teoriye, teorinin de kanuna dönüşeceği görüşündeki A seçeneğini işaretledikleri görülmüştür. Fen bilgisi öğretmen adaylarının \% 15.8'inin sınıf öğretmeni adaylarının \% 6.2'sinin Gerçekçi bakış açısına sahip olduğu, öğretmen adaylarının büyük bir çoğunluğunun ise Yetersiz bakış açısına sahip olduğu tespit edilmiştir (Fen bilgisi öğretmen adayları \% 84.2, sınıf öğretmeni adayları \% 93.8). Elde edilen bu bulguya göre, öğretmen adaylarının hipotez, teori ve kanun arasında bir hiyerarşinin olduğu ile ilgili kavram yanılgılarının olduğu söylenebilir (Şekil 16).

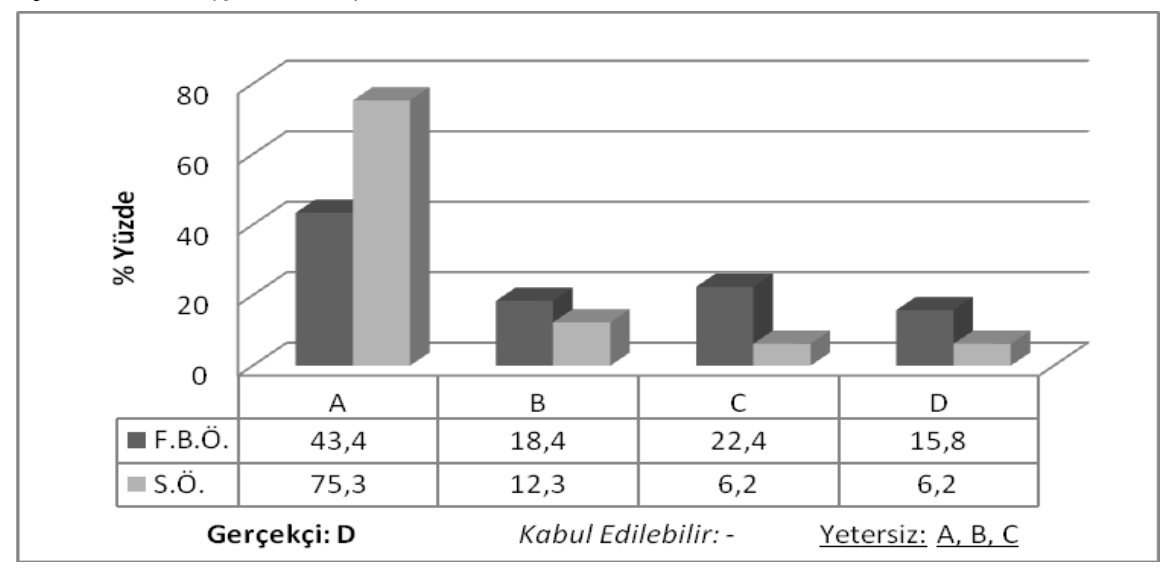

Şekil 16. Fen bilgisi ve sınıf öğretmeni adaylarının Bilimsel Bilginin Doğası (Hipotezler, teoriler ve kanunlar, tanımı, varsayımların rolü, inançlar) sorusuna verdikleri cevapların yüzdesi

Fen bilgisi ve sınıf öğretmeni adaylarının bilimsel bilginin doğasına yönelik görüşleri arasında anlamlı bir farklılık olup olmadığını belirlemek için ki-kare testi yapılmış ve anlamlı bir farklılık göstermediği tespit edilmiştir $\left(\mathrm{X}_{2}=3.344\right.$; $\left.\mathrm{p}>.05\right)$.

Hipotezler, Teoriler ve Kanunlar, Tanımı, Varsayımların Rolü, Inançlar (Bilimsel Bilginin Doğası) 
Bilimsel bilginin gelişmesi için tahminlerin etkisinin ne olduğu ile ilgili görüşleri ölçmeyi hedefleyen bu madde de, öğretmen adayların daha çok Kabul Edilebilir görüşlere sahip oldukları görülmektedir (fen bilgisi öğretmen adayları \% 67.1, sınıf öğretmeni adayları \% 72.7). Gerçekçi bakış açısının fen bilgisi öğretmen adayları (\% 23.7) ve sınıf öğretmeni adaylarında (\% 15.2) oldukça düşük oranlarda, Yetersiz bakış açısının ise sınıf öğretmeni adaylarında (\% 12.1), fen bilgisi ögretmen adaylarından (\% 9.2) daha fazla olduğu tespit edilmiştir (Şekil 17).

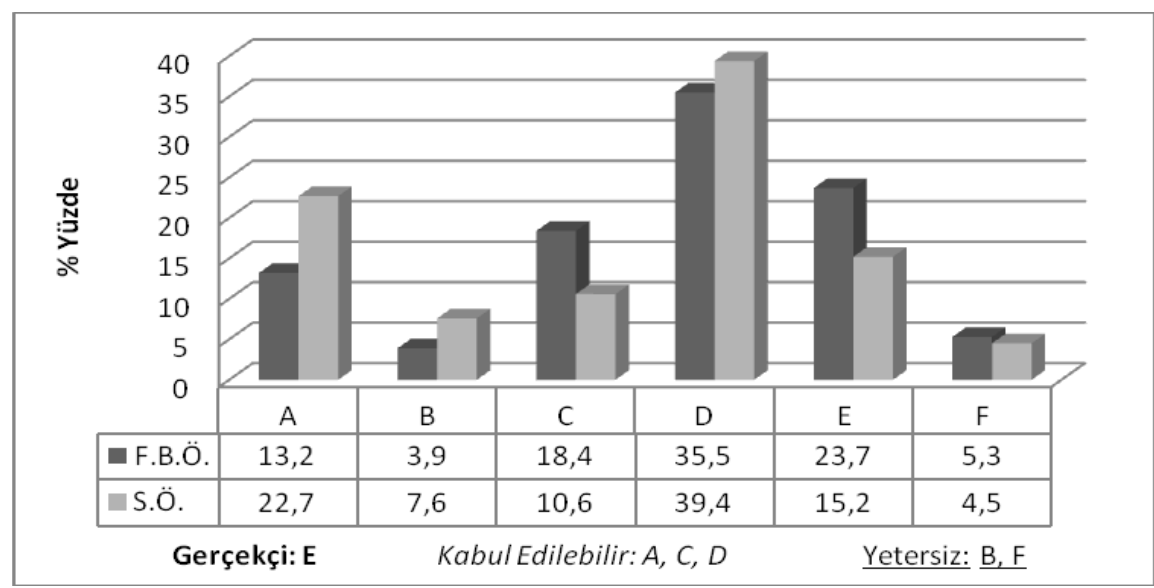

Şekil 17. Fen bilgisi ve sınıf öğretmeni adaylarının Hipotezler, teoriler ve kanunlar, tanımı, varsayımların rolü, inançlar (Bilimsel Bilginin Doğası) sorusuna verdikleri cevapların yüzdesi

Fen bilgisi ve sınıf öğretmeni adaylarının bilimsel bilginin doğası yönelik görüşleri arasında anlamlı bir farklılık olup olmadığını anlamak için yapılan ki-kare testi sonuçlarına göre anlamlı bir farklılık göstermediği tespit edilmiştir $\left(\mathrm{X}_{2}=1.748 ; \mathrm{p}>.05\right)$.

Hipotezler, Teoriler ve Kanunlar, Tanımı, Varsayımların Rolü,

\section{Inançlar (Bilimsel Bilginin Doğası)}

Teorilerin özellikleri ile ilgili katılımcıların bakış açısını ortaya çıkarmayı amaçlayan on sekizinci maddede Gerçekçi bakış açısını ifade eden $\mathrm{A}$ ve $\mathrm{C}$ seçenekleri içinden fen bilgisi öğretmen adaylarının 
\% 21.1'i, sınıf öğretmeni adaylarının \% 25.7'si daha çok C seçeneğini işaretlemişlerdir. Buradan hareketle sınıf öğretmeni adaylarının, fen bilgisi öğretmen adaylarına göre daha Gerçekçi bakış açısına sahip oldukları söylenebilir. Teorilerin özellikleri ile ilgili fen bilgisi öğretmen adaylarının (\% 60.5), sınıf öğretmeni adaylarından (\% 50.0) daha Kabul Edilebilir yanıtlar verdikleri tespit edilmiştir. Yetersiz bakış açısına ise fen bilgisi öğretmen adaylarının (\% 11.8), sınıf öğretmeni adaylarından yaklaşık iki kat (\% 7.6) fazla sahip oldukları görülmüştür (Şekil 18).

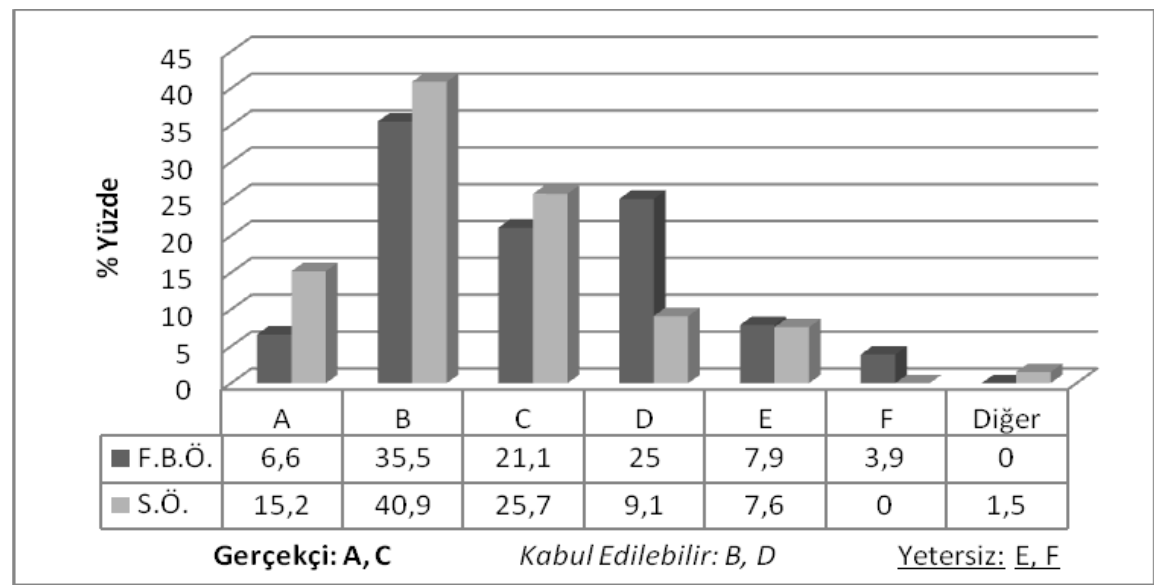

Şekil 18. Fen bilgisi ve sınıf öğretmeni adaylarının Hipotezler, teoriler ve kanunlar, tanımı, varsayımların rolü, inançlar (Bilimsel Bilginin Doğası) sorusuna verdikleri cevapların yüzdesi

Fen bilgisi ve sınıf öğretmeni adaylarının bilimsel bilginin doğasına yönelik görüşleri arasında anlamlı bir farklılık olup olmadığını belirlemek için yapılan ki-kare testi sonuçlarına göre anlamlı bir farklılık göstermediği tespit edilmiştir $\left(X_{2}=3.193 ; p^{>} .05\right)$.

Araştırmalar İçin Bilimsel Yaklaşım Bilimsel Metot (Bilimsel

\section{Bilginin Dŏgast)}

Anketin bilimsel metodun varlığı ile ilgili on dokuzuncu sorusunda Gerçekçi bakış açısını temsil eden $\mathrm{C}$ seçeneğini fen bilgisi 
öğretmen adayları \% 25.0 ve sınıf öğretmeni adayları \% 15.2 oranında işaretleyerek, bilimsel çalışmalarda bilim insanlarının yaratıcılık ve hayal gücünün ne kadar önemli olduğuna inandıklarını göstermişlerdir. Bununla birlikte $\mathrm{C}$ seçeneğindeki ifadenin tam tersi olan bilim insanlarının mantıklı ve kesin sonuçlar sağlaması nedeniyle bilimsel yöntemi izlediğini söyleyen A seçeneğinin öğretmen adayları tarafindan fazla tercih edilmesi dikkat çeken bir bulgu olmuştur (fen bilgisi öğretmen adayları \% 35.5, sınıf öğretmeni adayları \% 53). Bilimsel metodun varlığı ile ilgili Kabul Edilebilir seçenekleri fen bilgisi öğretmen adaylarının \% 50.0'si, sınıf öğretmen adaylarının ise \% 66.6'sı seçmişlerdir. Bu sonuca göre, sınıf öğretmeni adaylarının fen bilgisi öğretmen adaylarına göre daha fazla Kabul Edilebilir bakış açısına sahip olduğu tespit edilmiştir.

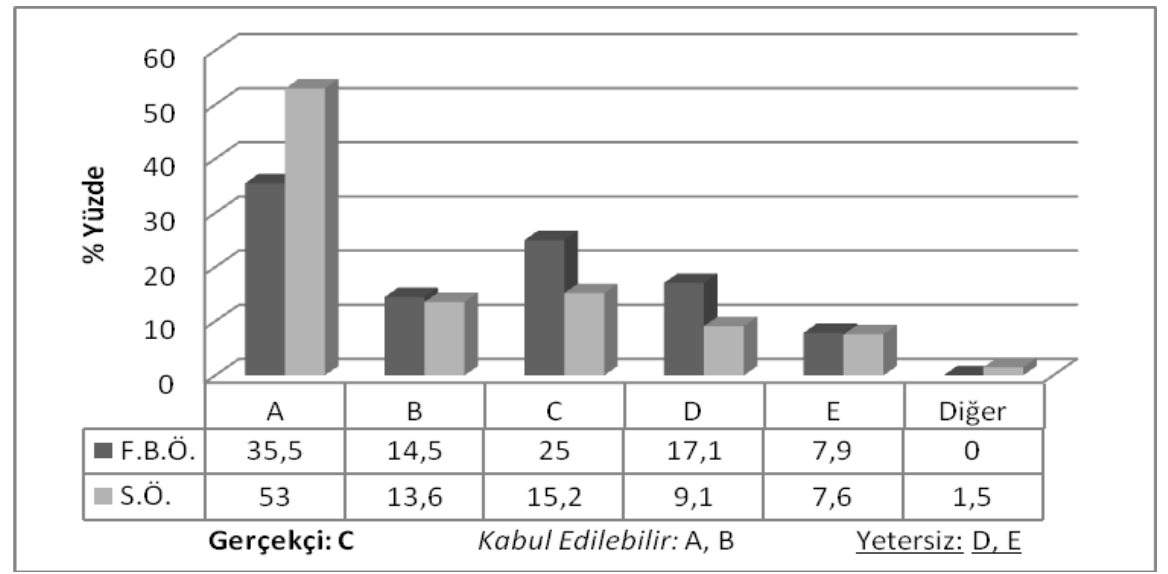

Şekil 19. Fen Bilgisi ve Sınıf Öğretmeni Adaylarının Araştırmalar İçin Bilimsel Yaklaşım Bilimsel Metot (Bilimsel Bilginin Doğası) Sorusuna Verdikleri Cevapların Yüzdesi

Fen bilgisi ve sınıf öğretmeni adaylarının bilimsel bilginin doğasına yönelik görüşleri arasında anlamlı bir farklılık olup olmadığını belirlemek için ki-kare testi yapılmış ve anlamlı bir farklılık göstermediği tespit edilmiştir $\left(\mathrm{X}_{2}=4.535\right.$; $\left.\mathrm{p}>.05\right)$. 
N.Yenice,B.Özden.../EÜ Ĕ̆itim Fakültesi Dergisi,17(1)(2015), 237-281

Araştırmalar İçin Bilimsel Yaklaşım, Bilimsel Metot (Bilimsel

\section{Bilginin Doğası)}

Bilim insanlarının hata yapıp yapmamalarının bilimsel bilgiye nasıl bir etkisinin olabileceği ile ilgili görüşleri belirlemeyi hedefleyen anketin yirminci sorusu için fen bilgisi (\% 47.4) ve sınıf öğretmeni (\% 41.6) adaylarının benzer oranlarda Kabul Edilebilir görüşlere sahip oldukları tespit edilmiştir. Gerçekçi bakış açısını ifade eden C seçeneği fen bilgisi öğretmen adaylarının \% 42.1'i, sınıf öğretmeni adaylarının \% 27.7'si tarafından işaretlenmiştir. Yetersiz bakış açısını ifade eden A ve E seçenekleri öğretmen adayları tarafından daha az tercih edilmiştir (fen bilgisi öğretmen adayları \% 10.5, sınıf öğretmeni adayları \% 29.2, Şekil 20).

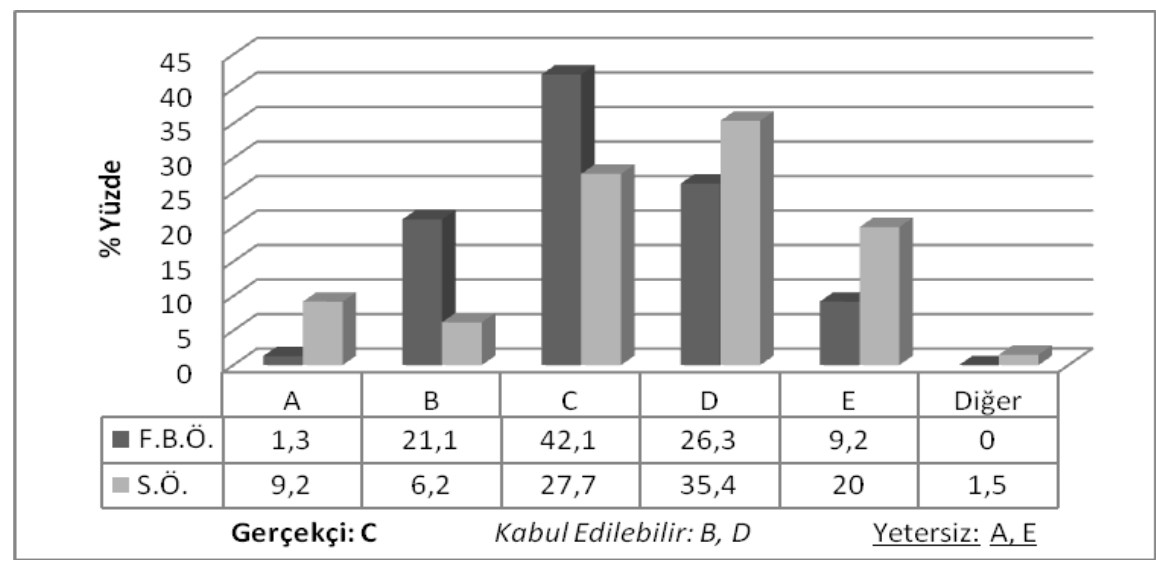

Şekil 20. Fen Bilgisi ve Sınıf Öğretmeni Adaylarının Araştırmalar İçin Bilimsel Yaklaşım, Bilimsel Metot (Bilimsel Bilginin Doğası) Sorusuna Verdikleri Cevapların Yüzdesi

Fen bilgisi ve sınıf öğretmeni adaylarının bilimsel bilginin doğasına yönelik görüşleri arasında anlamlı bir farklılık olup olmadığını belirlemek için ki-kare testi yapılmış ve anlamlı bir farklılık gösterdiği tespit edilmiştir $\left(\mathrm{X}_{2}=8.723 ; \mathrm{p}<.05\right)$. 


\section{Bilimsel/Teknolojik Bilginin Kesinliği ve Belirsizliği,}

\section{İhtimalleri (Bilimsel Bilginin Doğası)}

Bilimsel bilginin belirsizliği ile ilgili olan yirmi birinci madde de hiç kimsenin geleceği kesin olarak tahmin edemeyeceğini söyleyen A seçeneği, fen bilgisi öğretmen adayları (\% 44.8) ve sınıf öğretmeni adayları tarafindan (\% 54.4) en çok tercih edilen seçenek olmuştur. Bilimsel bilginin kesin olmaması ile ilgili sınıf öğretmeni adaylarının (\% 62), fen bilgisi öğretmen adaylarına (\% 52.7) göre daha Gerçekçi bakış açısına sahip olduğu tespit edilmiştir (Şekil 21).

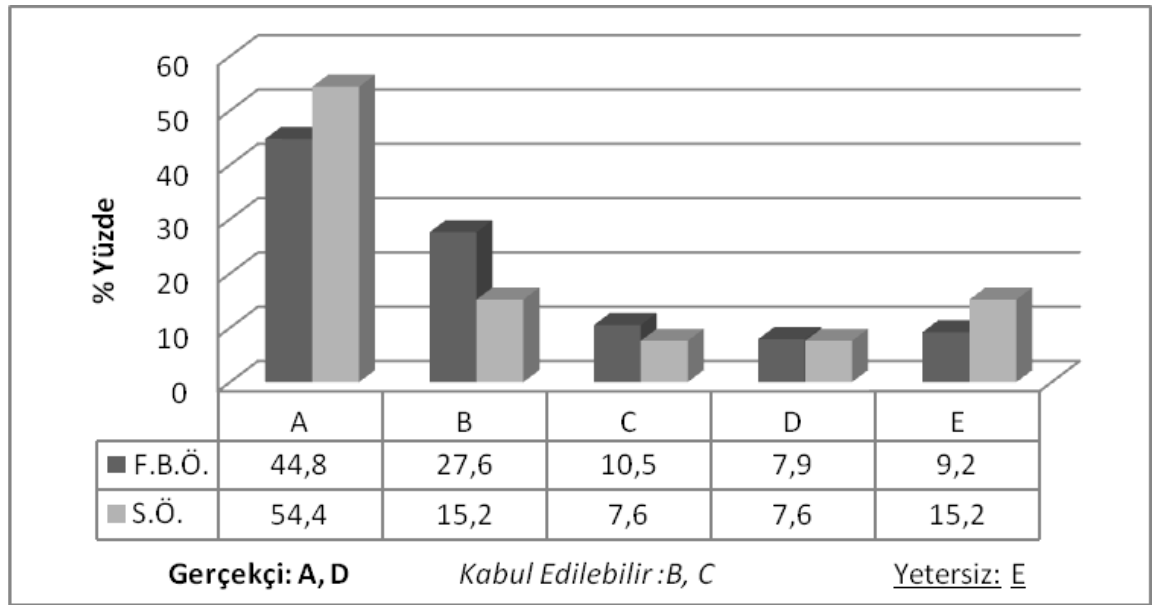

Şekil 21. Fen Bilgisi ve Sınıf Öğretmeni Adaylarının Bilimsel/Teknolojik Bilginin Kesinliği ve Belirsizliği, İhtimalleri Sorusuna Verdikleri Cevapların Yüzdesi

Fen bilgisi ve sınıf öğretmeni adaylarının bilimsel bilginin doğasına yönelik görüşleri arasında anlamlı bir farklılık olup olmadığını belirlemek için yapılan ki-kare testi sonuçlarına göre anlamlı bir farklılık gösterdiği tespit edilmiştir $\left(\mathrm{X}_{2}=4.313\right.$; $\left.\mathrm{p}>.05\right)$.

\section{Bilimsel Bilginin Epistemolojik Durumu (Bilimsel Bilginin}

\section{Doğasi)}

Bilim insanlarının kanunları icat ettiklerini ifade eden ve Gerçekçi görüşü yansıtan E seçeneği fen bilgisi öğretmen adaylarının 
\% 32.9'u, sınıf öğretmeni adaylarının ise \% 34.8'i tarafından işaretlenmiştir. Kabul Edilebilir bakış açısını yansıtan A ve C seçenekleri içinden kanunların her zaman doğada ortaya çıkartılmayı beklediğini ifade eden A seçeneği, hem fen bilgisi öğretmen adayları (\% 14.5), hem de sınıf öğretmeni adayları (\% 28.9) tarafindan daha çok tercih edilmiştir. Fen bilgisi öğretmen adaylarının \% 42.1'nin sınıf öğretmeni adaylarının da \%28.8'inin Yetersiz görüşlere sahip oldukları görülmektedir (Şekil 22).

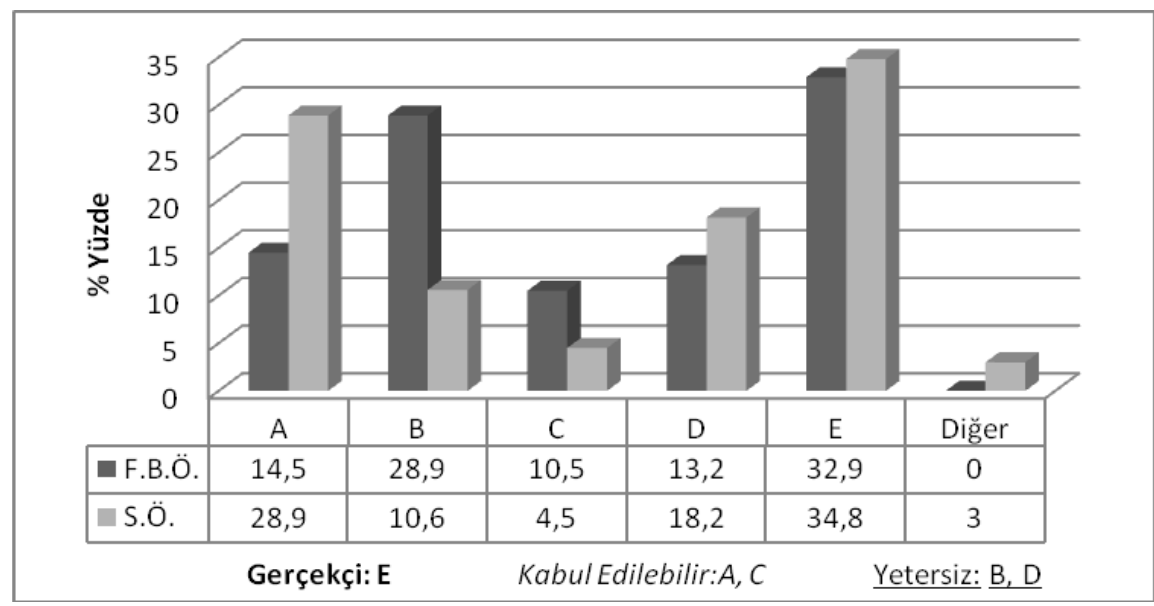

Şekil 22. Fen Bilgisi ve Sınıf Öğretmeni Adaylarının Bilimsel Bilginin Epistemolojik Durumu Sorusuna Verdikleri Cevapların Yüzdesi

Fen bilgisi ve sınıf öğretmeni adaylarının bilimsel bilginin doğası yönelik görüşleri arasında anlamlı bir farklılık olup olmadığını belirlemek için yapılan ki-kare testi sonuçlarına göre anlamlı bir farklılık göstermediği tespit edilmiştir $\left(\mathrm{X}_{2}=2.607\right.$; $\mathrm{p}>$.05).

\section{Bilimsel Bilginin Epistemolojik Durumu (Bilimsel Bilginin}

\section{Doğasi)}

Hipotezlerin icat mı yoksa keşfediliyor mu sorularını araştıran anketin yirmi üçüncü maddesinde fikirlerin her zaman doğada, açığa çıkartılmayı beklediğini söyleyen A seçeneği sınıf öğretmeni adayları tarafından $\% 25.8$, fen bilgisi öğretmen adayları tarafindan $\% 14.5$ 
oranında seçilmiştir. Hipotezlerin zihinden geldiğini, onları bizim oluşturduğumuzu söyleyen Gerçekçi bakış açısını ifade eden F seçeneğini sınıf öğretmeni adaylarının \% 7.6's1 ve fen bilgisi öğretmen adaylarının ise \% 9.2'si tercih etmiştir. Sınıf öğretmeni adaylarının (\% 57.6) ve fen bilgisi ögretmen adaylarının (\% 54) yarıdan fazlasının Yetersiz bakış açısına sahip olduğu tespit edilmiştir.

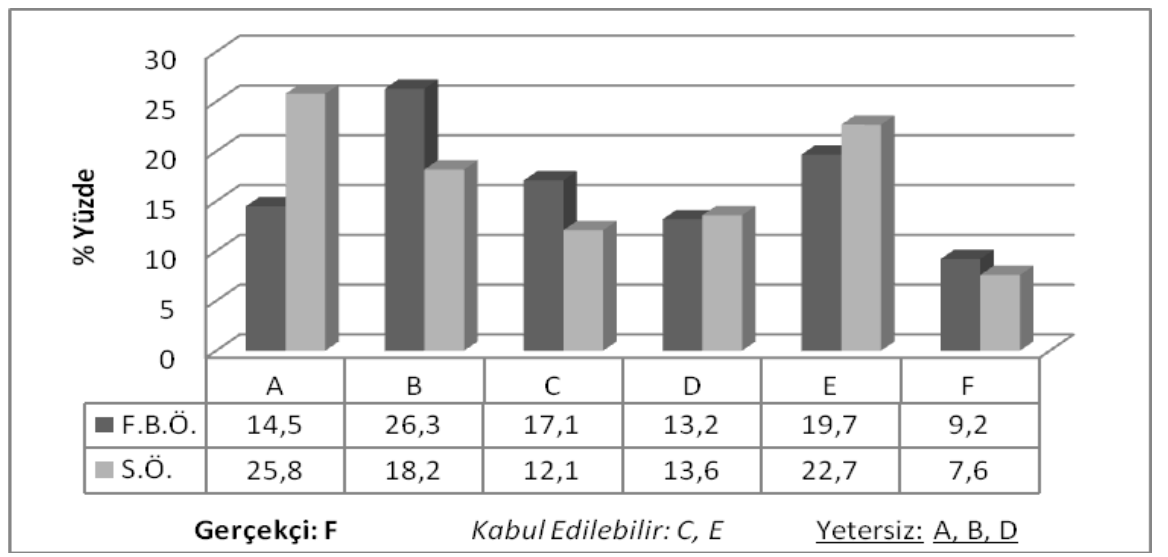

Şekil 23. Fen Bilgisi ve Sınıf Öğretmeni Adaylarının Bilimsel Bilginin Epistemolojik Durumu Sorusuna Verdikleri Cevapların Yüzdesi

Fen bilgisi ve sınıf öğretmeni adaylarının bilimsel bilginin doğasına yönelik görüşleri arasında anlamlı bir farklılık olup olmadığını belirlemek için ki-kare testi yapılmış ve anlamlı bir farklılık göstermediği tespit edilmiştir $\left(\mathrm{X}_{2}=.234\right.$; $\left.\mathrm{p}>.05\right)$.

\section{Bilimsel Bilginin Epistemolojik Durumu (Bilimsel Bilginin}

\section{Doğasi)}

Teorilerin icat mi yoksa keşfediliyor mu sorusunu araştıran yirmi dördüncü maddesinde Gerçekçi bakış açısını ifade eden E seçeneği fen bilgisi öğretmen adayları tarafından \% 15.8 ve sınıf öğretmeni adayları tarafından \% 21.1 oranlarında işaretlenmiştir. Kabul Edilebilir bakış açılarını yansıtan B ve C seçeneklerinden "Teorilerin deneysel gerçeklere dayandığ için bilim insanlarının teorileri keşfettiklerini" ifade eden B seçeneği sınıf öğretmeni adayları (\% 22.8), C seçeneği ise fen bilgisi öğretmen adayları (\% 34.2) 
tarafından daha çok işaretlenmiştir. Yetersiz görüşleri yansıtan A, D ve $F$ seçeneklerinin fen bilgisi öğretmen adaylarının \% 38.2, sınıf öğretmeni adaylarının ise \% 37.9 oranlarında işaretledikleri tespit edilmiştir (Şekil 24).

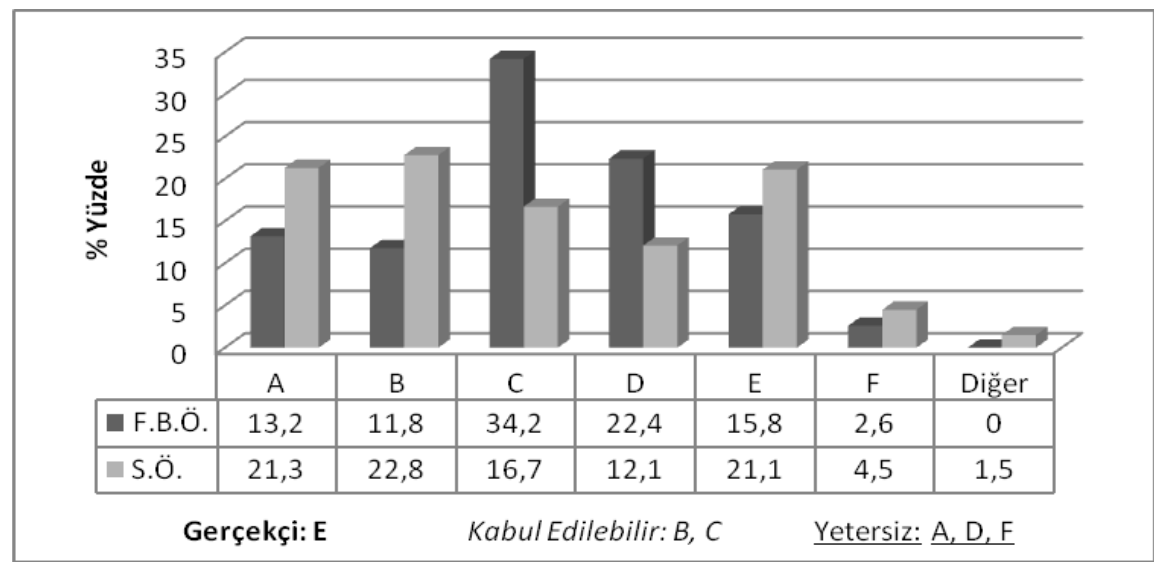

Şekil 24. Fen Bilgisi ve Sınıf Öğretmeni Adaylarının Bilimsel Bilginin Epistemolojik Durumu Sorusuna Verdikleri Cevapların Yüzdesi

Fen bilgisi ve sınıf öğretmeni adaylarının bilimsel bilginin doğasına yönelik görüşleri arasında anlamlı bir farklılık olup olmadığını belirlemek için yapılan ki-kare testi sonuçlarına göre anlamlı bir farkl11ık göstermediği tespit edilmiştir $\left(\mathrm{X}_{2}=.925 ; \mathrm{p}>.05\right)$.

\section{Bilimler Arası Kavramların Tutarlılı̆̆ı, Paradigması (Bilimsel}

\section{Bilginin Doğası)}

Bilimsel düşüncelerin bilim insanlarının bakış açısına veya onların alışkanlıklarına bağlı olduğunu söyleyen A seçeneği fen bilgisi öğretmen adayları tarafından \% 32.8 ve sınıf öğretmeni adayları tarafından \% 27.3 oranlarında seçilmiştir. Bu oranlara göre fen bilgisi öğretmen adaylarının sınıf öğretmeni adaylara göre daha Gerçekçi bakış açısına sahip olduğu söylenebilir. "Farkl alanlardaki bilimsel düşüncelerin kesiştiği, gerçeklerin bilimsel alan ne olursa olsun gerçek olduğu”, Kabul Edilebilir bakış açısını yansıtan E seçeneğini fen bilgisi öğretmen adaylarının \% 32.9'u, sınıf öğretmeni adaylarının \% 27.3'ü tercih etmişlerdir. Ayrıca sınıf öğretmeni adaylarının fen 
bilgisi öğretmen adaylarına göre daha fazla Yetersiz bakış açısına sahip olduğu tespit edilmiştir (Şekil 25).

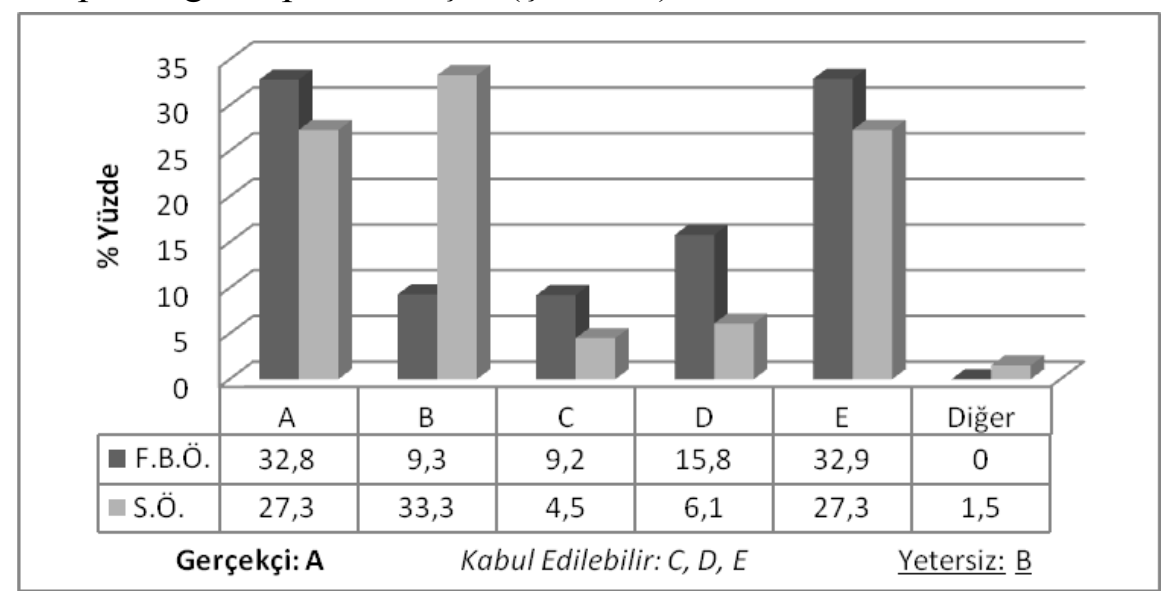

Şekil 25. Fen Bilgisi ve Sınıf Öğretmeni Adaylarının Bilimler Arası Kavramların Tutarlılı̆̆1, Paradigması Sorusuna Verdikleri Cevapların Yüzdesi

Fen bilgisi ve sınıf öğretmeni adaylarının bilimsel bilginin doğası yönelik görüşleri arasında anlamlı bir farklılık olup olmadığını belirlemek için ki-kare testi yapılmış ve anlamlı bir farklılık gösterdiği tespit edilmiştir $\left(\mathrm{X}_{2}=13.353 ; \mathrm{p}<.05\right)$.

\section{Sonuç ve Tartışma}

Fen bilgisi ve sınıf öğretmeni adayları bilimin tanımı konusunda ortak bir görüş ortaya koyamamakla birlikte, büyük oranda Kabul Edilebilir bakış açısına sahip oldukları görülmektedir. Ayrıca fen bilgisi öğretmen adaylarının sınıf öğretmeni adaylarına göre daha Gerçekçi bakış açısına sahip olduğu sonucuna ulaşılmıştır. İlgili alan yazın incelendiğinde, katılımcıların bilimin tanımı konusunda ortak bir görüş birliğine varamadığı çalışmalar mevcuttur (Arı, 2010; Aslan, 2009; Beşli, 2008; Doğan Bora, 2005; Kenar, 2008; Saraç, 2012). Dolayısıyla, mevut çalışma bulguları ile alan yazındaki çalışma bulgularının birbirini desteklediği söylenebilir. 
Fen bilgisi öğretmen adayları toplumun bilim üzerine etkisi ile ilgili görüşlerini ölçen anketin iki maddesi için daha çok Gerçekçi ve Kabul Edilebilir görüşler belirtirken; sınıf öğretmeni adayları daha çok Gerçekçi ve Yetersiz görüşler belirtmişlerdir. Bununla birlikte, fen bilgisi öğretmen adaylarının (\% 78.9) ve sınıf öğretmeni adaylarının (\% 63.3) büyük çoğunluğu bilimsel çalışmaların yapıldığı yerdeki dini, ahlaki ve kültürel öğelerden etkilendiğini belirten görüşler ortaya koymuşlardır. Benzer şekilde, Aikenhead (1987), Aslan (2009), Beşli (2008), Doğan Bora (2005) ve Saraç (2012) yaptıkları çalışmalarda katılımcıların toplumun bilimsel araştırmaları etkilediği yönde görüşler belirtikleri sonucuna ulaşmışlardır. Buna karşın, Lederman vd. (2002) ve Liu vd. (2007) yaptıkları araştırmalarda sosyal ve kültürel değerlerin bilime etkisinin olmadığ görüşlerini tespit etmişlerdir. Ailelerin, toplumun ve okulun yetiştirme tarzlarının bilim insanına etkisi ile ilgili fen bilgisi öğretmen adaylarının ( $\%$ 63.2) ve sınıf öğretmeni adaylarının ( $\%$ (\% 59.1$)$ yarısından fazlasının Gerçekçi görüşlere sahip olduğu sonucuna ulaşılmıştır. Buradan hareketle, öğretmen adaylarının bilim insanı yetiştirmede çocuk yetiştirme tarzının etkili olduğunu düşündükleri söylenebilir. İlgili alan yazın incelendiğinde, mevcut araştırma bulgularının Doğan Bora'nın (2005), Beşli'nin (2008) ve Aslan'nın (2009) fen bilgisi öğretmen ya da öğretmen adayları ile Saraç'ın (2012) sınıf öğretmeni ve öğretmen adayları ile yaptığı araştırmaların sonuçları ile paralellik gösterdiği görülmektedir.

Bilimin toplum üzerine etkisi ile ilgili fen bilgisi öğretmeni ve sınıf öğretmeni adaylarının hem Gerçekçi hem de Yetersiz görüşlere sahip oldukları belirlenmiştir. Bilim insanlarının buluşların meydana getireceği sonuçların etkileriyle ilgilenmeleri konusunda fen bilgisi öğretmen adayları sınıf öğretmeni adaylarına göre daha yetersiz görüşler belirtmişlerdir. Saraç (2012) çalışmasında sınıf öğretmeni ve öğretmen adaylarının \% 43.3'ünün Yetersiz görüş belirttiği sonucuna ulaşmıştır. Doğan Bora (2005) çalışmasında fen bilgisi öğretmenlerinin \% 41.7'sinin Gerçekçi; \% 25.5'inin Yetersiz bakış açısına sahip olduğunu belirlemiştir. Bilimsel olaylarda verilecek kararlarda, uzmanların ve bilgilendirilmiş toplumun görüşlerinin eşit oranda dikkate alınması gerektiği Gerçekçi görüşünü fen bilgisi öğretmen adayları (\% 47.4) ve sinıf öğretmeni adayları (\% 42.5) 
yüksek ve benzer oranlarda ifade etmişlerdir. $\mathrm{Bu}$ maddeden elde edilen sonuçlar; Doğan Bora'nın (2005) fen bilgisi öğretmen ve adayları ve Saraç'ın (2012) sınıf öğretmeni ve öğretmen adayları ile yaptığı görüşmelerden elde ettiği sonuçlarla benzer özellikler sergilemektedir. Buna karşın; Beşli'nin (2008) araştırmasında bu madde için belirtilen görüşlerde sadece bilim insanlarının karar alması düşüncesi daha fazla belirtilmiştir. Bilim insanlarının karşılaştıkları gündelik problemleri en iyi şekilde çözüp çözmedikleri ile ilgili madde için hem fen bilgisi öğretmen adayları (\% 53.9), hem de sınıf öğretmeni adayları (\% 56.1) bilim insanlarının diğer insanlardan daha bilgili olduğu görüşünü ifade ederek Gerçekçi bir bakış ortaya koymuşlardır. Beşli (2008) ve Saraç (2012) araştırmalarında aynı sonuca ulaşırken, Doğan Bora (2005) çalışmasında fen bilgisi öğretmenlerinin ve öğretmen adaylarının bilim insanlarının günlük yaşantıdan uzak yaşayarak çalıştıkları için daha kötü olabileceklerini düşündüklerini tespit etmiştir.

Bilim insanının karakteristik özellikleri ile ilgili olarak ankette yer alan maddeler için fen bilgisi ve sınıf öğretmeni adaylarının hem Gerçekçi hem de Yetersiz görüşlere sahip oldukları sonucuna ulaşılmıştır. Başarılı bilim insanlarının araştırmalarında daima çok açık fikirli, mantıklı, önyargısız ve tarafsız olması; bu özelliklere ek olarak hayal gücü, zeka, dürüstlük gibi başka özelliklerin de olması gerektiği konusunda fen bilgisi ve sınıf öğretmeni adaylarının Gerçekçi görüşlere yüksek ve benzer oranlarda sahip oldukları belirlenmiştir. Bu sonuç, Aslan'ın (2009), Doğan Bora'nın (2005) ve Saraç'ın (2012) yaptığı araştırma sonuçları ile paralellik göstermektedir. Bilim insanlarının sosyal hayatları ile ilgili, sınıf öğretmeni adayları (\% 34.8) bilim insanlarının sosyal hayatının kişiye bağlı olduğunu belirtirken; fen bilgisi öğretmen adayları (\%60.5) bilim insanlarının sosyal hayatlarının farklı olabileceğini ama bunun sosyal yaşantıları olmadığı anlamına gelmediğini ifade eden Gerçekçi görüşüne sınıf öğretmeni adaylarından daha çok katıldıkları tespit edilmiştir. İlgili alan yazın incelendiğinde mevcut araştırma bulguları Doğan Bora'nın (2005) ve Saraç'ın (2012) yaptığı araştırma sonuçları ile paralellik göstermektedir. Bilimsel buluşlarda cinsiyetin etkisinin olup olmadığı ile ilgili görüşlerin alındığı madde incelendiğinde fen bilgisi öğretmen adaylarının (\% 55.3) sınıf öğretmeni adaylarına (\% 
30.3) göre daha Gerçekçi bakış açısına sahip olduğu bulunmuştur. Yetersiz bakış açısına ise; sınıf öğretmeni adaylarının (\% 47.1) fen bilgisi öğretmeni adaylarına (\% 31.6) göre daha fazla sahip olduğu tespit edilmiştir. $\mathrm{Bu}$ durum bilimsel buluşlarda fen bilgisi öğretmen adaylarının kadın-erkek eşitliğine sınıf öğretmeni adaylarına göre daha olumlu düzeyde baktığının bir göstergesi olabilir. İlgili alan yazın incelendiğinde, Doğan Bora (2005), Beşli (2008) ve Saraç'ın (2012) yaptığı çalışma bulgularının eldeki araştırma bulgusunu desteklediği söylenebilir.

Bilim insanlarının bazen paylaşma, dürüstlük ve bağımsızlık gibi bilimin kurallarını çiğneyip çiğnemedikleri ile ilgili ifadelerin bulunduğu madde incelendiğinde, öğretmen adaylarının Kabul Edilebilir görüşlere sahip oldukları görülmüş̧tür. Fen bilgisi öğretmeni adaylarının (\% 17.1) sınıf öğretmeni adaylarına (\% 7.6) göre düşük düzeyde de olsa daha çok Gerçekçi bakış açısına sahip olduğu tespit edilmiştir. Doğan Bora (2005) ve Saraç (2012) çalışmalarında öğretmen adaylarının bilim insanlarının bilimin kurallarını çiğneyip

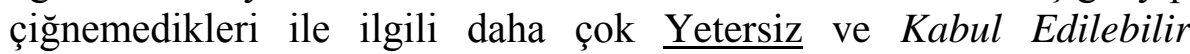
görüsslere sahip olduklarını belirlemişlerdir. $\mathrm{Bu}$ bulgu günümüz toplumunda rekabetin kaçınılmaz bir durum olmasından kaynaklandığı söylenebilir. Özellikle son yıllarda öğretmenlerin atanmaları sırasında yaşanan rekabetin bu sorunun cevabına da yansıdığı düşünülmektedir (Saraç, 2012).

Bilim insanının sosyal ilişkileri ile bilimsel çalışmalar arasındaki ilişki için bu ilişkilerin bilim insanlarını gözlem yapmaya teşvik ettiği ve toplumsal araştırmalar için teşvik ettiği düşüncesini ifade eden Kabul Edilebilir görüşlere fen bilgisi öğretmen adaylarının (\% 47.7) ve sınıf öğretmeni adaylarının (\% 47.0) benzer oranlarda cevap verdiği tespit edilmiştir. Aynı zamanda bilim insanlarının etkileşim içinde oldukları insanların fikirlerinden, deneyimlerinden yararlandığını söyleyen Gerçekçi görüşü ifade eden seçeneğini de öğretmen adayları en çok tercih etmişlerdir. $\mathrm{Bu}$ bulgu, öğretmen adaylarının bilim insanlarının etraflarındaki kişilerin görüşlerini önemsediğine inandıklarının bir göstergesi olabilir. Doğan Bora'nın (2005) fen bilgisi öğretmenleri ve adayları ile ve Saraç'ın (2012) sınıf öğretmeni ve adayları ile yaptığı çalışmalarda da benzer sonuçlara ulaşmıştır. 
Bilim insanlarının sahip oldukları inançların yaptıkları gözlemler üzerine etkisi ile ilgili fen bilgisi (\% 82.9) ve sinıf öğretmeni (\% 83.3) adaylarının Gerçekçi görüşlere yüksek ve benzer oranlarda sahip oldukları belirlenmiştir. Aslan (2009) çalışmasında bu durumu aynı nesneye veya manzaraya aynı yerden bakan iki gözlemcinin aynı şeyleri görebilecekleri düşünülse de gözlemcilerin gördüğü şey, geçmiş tecrübelerine, bilgisine ve beklentilerine bağlı olduğu şeklinde açıklamıştır. Bilimsel modellerin gerçeğin kopyası olup olmadığı ile ilgili sınıf öğretmeni adaylarının, fen bilgisi öğretmen adaylarına göre daha fazla bilimsel modellerin gerçeğin kopyası olduğunu yansıtan Yetersiz görüşlere sahip oldukları sonucuna ulaşılmıştır. İlgili alan yazın incelendiğinde, bilimin doğası ile ilgili bu özelliğin ölçüldüğü pek çok çalışmada katılımcıların bu konuda yetersiz görüşlere sahip oldukları bulunmuştur (Arı, 2010; Doğan Bora, 2005; Erdoğan, 2004; Lederman ve ark., 2002; Liu ve ark., 2007; Palmquist ve ark., 1997; Saraç, 2012;). Bilim insanlarının doğada yaptıkları sınıflandırmalar hakkındaki bakış açılarını ortaya çıkarmayı hedefleyen madde bulguları incelendiğinde, fen bilgisi öğretmen adaylarının (\% 50.0), sınıf öğretmeni adaylarına (\% 40.9) göre daha Gerçekçi bakış açısına sahip olduğu görülmektedir. $\mathrm{Bu}$ bulgu Ar1 (2010), Aslan (2009), Doğan Bora (2005), Erdoğan (2004) ve Saraç 'ın (2012) çalışmalarının sonuçları ile örtüşmektedir.

Bilimsel bilginin değișebilirliği ile ilgili sınıf öğretmeni adaylarının (\% 50.0), fen bilgisi öğretmen adaylarına (\% 40.9) göre daha Gerçekçi bakış açısına sahip olduğu sonucuna ulaşılmıştır. Bu sonuca göre öğretmen adaylarının bilimsel bilgininin değişebilirliği konusunda çağdaş bilim anlayışına inandıkları söylenebilir. Bu sonuçlar ilgili alan yazındaki diğer araştırmaların sonuçlarıyla benzerlik göstermektedir (Ar1, 2010; Aslan, 2009; Beşli, 2008; Doğan Bora, 2005; Saraç, 2012).

Hipotez, teori ve kanun arasında bir hiyerarşi olup olmadiğı ile ilgili fen bilgisi (\% 84.2) ve sınıf öğretmeni adaylarının (\% 93.8) büyük çoğunluğunun Yetersiz görüşler belirttiği sonucuna ulaşılmıştır. Fen bilgisi öğretmen adaylarının \% 43.4'ü ve sınıf öğretmeni adaylarının \% 75.4'ü "hipotez teoriye, teori kanuna dönüşebilir"

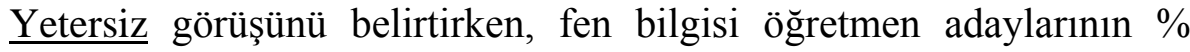
15.8 'i ile sınıf öğretmeni adaylarının \% 6.2'si “Teoriler kanun olamaz; 
çünkü kanunlar olguları genel olarak tanımlar, teoriler ise bu kanunları açıklar" Gerçekçi görüşünü ortaya koymuşlardır. McComas' in (2000) da belirttiği gibi bu durum bilimsel fikirlerin hiyerarşik bir yapısının bulunduğu ile ilgili yanlış inanışla açıklanabilir. Bu bulguya göre öğretmen adaylarının geleneksel bilim anlayışına inandıkları söylenebilir. Hipotez-teori ve yasa arasında bir hiyerarşi olduğu kavram yanılgısına literatürdeki araştırmalarda da oldukça sık rastlanmaktadır (Abd-El Khalick, 2006; Arı, 2010; Aslan, 2009; Doğan Bora, 2005; Erdoğan, 2004; Kenar, 2008; Liu ve ark., 2007; Parker ve ark., 2008; Ryan ve ark., 1992; Saraç, 2012; Tatar ve ark., 2011). Bilimsel bilginin gelişmesi ile tahminler arasındaki ilişki ile ilgili sınıf öğretmeni adaylarının (\% 72.7), fen bilgisi öğretmen adaylarına (\% 67.1) göre daha çok Kabul Edilebilir görüşlere sahip oldukları sonucuna ulaşılmıştır. Aynı şekilde, teorilerin özellikleri ile ilgili de, sınıf öğretmeni adaylarının (\% 40.9), fen bilgisi öğretmen adaylarına (\% 27.6) göre "Bazı iyi teoriler basit, bazıları ise karmaşık olabilir" şeklindeki görüşleri ile daha fazla Gerçekçi bakış açısına sahip olduğu tespit edilmiştir. İlgili alan yazın incelendiğinde Arı (2010), Doğan Bora (2005) ve Saraç'ın (2012) yaptığı çalışma bulgularıyla eldeki araştırma bulgularının birbirini desteklediği söylenebilir.

Bilimsel yöntem basamakları ve bilim insanlarının çalışmalarındaki hatalar ile ilgili katılımcılar genel olarak Kabul Edilebilir görüşler yansıtmışlardır. Fen bilgisi (\% 47.4) ve sınıf öğretmeni adayları (\% 41.6) bilim insanlarının geçerli, açık, mantıklı sonuçlar sağlaması ve bilimsel yöntemin bir çok bilim insanı için uygun olması nedenleriyle bilimsel yöntem basamaklarının kullanıldığı Kabul Edilebilir görüşlerini belirtmişlerdir. Abd-El Khalick (2001) fen bilgisi öğretmen adaylarıyla gerçekleştirdiği çalışmasında adayların "Doğru ve kesin bilgiye tek bir bilimsel yöntemle ulaşılabilinir" şeklindeki geleneksel görüşlerini tespit etmiştir. "Hatalar bilimin ilerlemesini yavaşlatır ve bazı hatalar yeni ve büyük buluşlara neden olabilir" Kabul Edilebilir görüşlerini de fen bilgisi öğretmen adaylarının \% 47.4' ünün ve sınıf öğretmeni adaylarının \% 41.6'sının ifade ettiği sonucuna ulaşılmıştır.

Bilimsel bilginin kesinliği ve belirsizliği ile ilgili hem fen bilgisi hem de sınıf öğretmeni adaylarının yarısından fazlası Gerçekçi 
görüşler belirtmişlerdir. Bilimsel bilginin kesin olmaması ile ilgili sınıf öğretmeni adayları (\% 62.1), fen bilgisi öğretmen adaylarına (\% 52.6) göre daha Gerçekçi bakış açısına sahiptir. Bu sonuca göre sınıf öğretmeni adayların fen bilgisi öğretmen adaylarına göre daha yüksek oranda geleceği kimsenin kesin olarak tahmin edemeyeceğini ve bazı bilgilerin daima eksik olduğunu düşündükleri söylenebilir. İlgili alan yazın incelendiğinde Doğan Bora (2005) ve Saraç'ın (2012) yaptığı çalışma bulgularıyla eldeki araştırma bulgularının birbirini desteklediği söylenebilir.

Bilimsel bilginin epistemolojik durumu ile ilgili görüşleri ortaya çıkarmayı hedefleyen anketin üç maddesi içinde öğretmen adaylarının Yetersiz ve Kabul Edilebilir görüşlere sahip oldukları tespit edilmiştir. Fen bilgisi öğretmen adaylarının \% 32.9'unun, sınıf öğretmeni adaylarının ise \%34.8'inin "Bilim insanları bilimsel kanunları icat ederler” gerçekçi görüşüne sahip olduğu sonucuna ulaşılmıştır. Hipotezlerin icat $\mathrm{ml}$ yoksa keşfediliyor mu sorusuna öğretmen adaylarının verdikleri cevap incelendiğinde sınıf öğretmeni adaylarının (\% 57.6) ve fen bilgisi öğretmen adaylarının (\% 53.9) yarıdan fazlasının Yetersiz bakış açısına sahip olduğu belirlenmiştir. Teorilerin icat mı yoksa keşfediliyor mu sorusuna fen bilgisi öğretmen adaylarının \% 46.1'inin ve sınıf öğretmeni adaylarının \% 39.4'ünün Kabul Edilebilir cevaplar verdiği sonucuna ulaşılmıştır. Öğretmen adaylarının bilimsel bilginin epistemolojik durumu ile ilgili maddelere verdikleri cevaplar incelendiğinde, öğretmen adaylarının geleneksel bilim anlayışına daha yakın düşüncelere sahip oldukları söylenebilir. Çalışmanın bu sonucuna benzer sonuçlara diğer araştırmalarda da rastlanmaktadır (Aslan, 2009; Doğan Bora, 2005; Erdoğan, 2004; Ryan ve ark., 1992; Saraç, 2012 ).

Bilimsel çalışmaların bilim insanlarının bakış açıları ile ilişkileri hakkında fen bilgisi (\% 57.9) ve sınıf öğretmeni adaylarının (\% 37.9) Kabul Edilebilir görüşlere sahip oldukları görülmüştür. Bu sonuca göre öğretmen adayları genel olarak, bilim insanlarının zeki olduklarını, aynı anda değişik alanlarda çalışmış olabileceklerini ve bilimsel düşünceler örtüştüğü için bilim insanlarının birbirlerini anlamalarının kolay olduğunu düşünmektedirler. İlgili alan yazın incelendiğinde Doğan Bora (2005), Saraç (2012) ve Arı'nın (2010) 
çalışma sonuçlarının eldeki araştırma bulgusuyla örtüştüğü görülmektedir.

Öğretmen adaylarının bilimin doğasına yönelik görüşlerinin öğrenim gördükleri anabilim dalı değişkenine göre; toplumun bilim üzerindeki etkisi, bilim insanlarının karakteristik özellikleri, bilimsel bilginin doğası alt boyutlarında istatistiksel olarak anlamlı bir farklılık gösterdiği tespit edilmiştir. Diğer alt boyutlarda fen bilgisi ve sinıf öğretmeni adaylarının birbirine benzer cevaplar vererek, anlamlı bir farklılığın olmadığı sonucuna ulaşılmıştır. Arı (2010) çalışmasında, öğretmen adaylarının bilimin doğası hakkında bazı kavram yanılgılarına sahip olduklarını tespit etmiştir. Aynı zamanda, öğretmen adaylarının öğrenim gördükleri anabilim dallarına göre istatistiksel olarak anlamlı bir farklılık olduğu sonucuna ulaşmıştır.

Çalışmadan elde edilen sonuçlar doğrultusunda aşağıdaki öneriler geliştirilmiştir.

- $\quad$ Fen bilgisi ve sınıf öğretmeni adaylarına bilimsel bilginin nasıl üretildiği, kullanıldığı ile ilgili kavram yanılgılarını ortadan kaldırabilecek etkinlikler düzenlenebilir.

- $\quad$ Sınıf öğretmeni adaylarına yönelik olarak bilimin doğası hakkında çağdaş bakış açısı kazandıracak etkinlikler hazırlanıp uygulanarak bilimin doğasını daha iyi anlamaları sağlanabilir.

- $\quad \mathrm{Bu}$ çalışma fen bilgisi ve sınıf öğretmeni adayları ile gerçekleştirilmiş olup nicel veriler üzerinde çalışılarak genellemelere ulaşılmıştır. Araştırma sonucunda daha net genellemelere ulaşabilmek için nitel çalışmalar yapılması önerilebilir.

\section{Kaynaklar}

AAAS, 1993. Science for all Americans: Project 2061. Oxford University Press, New York.

Abd-El-K.Halick, F., Bell, R.L. \& Lederman, N. G. (1998). The Nature of Science And Instructional Practice: Making The Unnatural Natural. Science Education, 82, 417-436.

Abd-El-Khalick, F. \& Lederman, N. G. (2000). Improving Science Teachers' Conceptions of Nature of Science: A Critical Review of the Literature. International Journal of Science Education. 22, 665-701. 
Abd-El-Khalick, F. (2001). Embedding Nature of Science Instruction in Preservice Elementary Science Courses: Abandoning Scientism, But. Journal of Science Teacher Education. 12(3), 215-233.

Abd-El-Khalick, F. (2006). Preservice and Experienced Biology Teachers' Global and Specific Subject Matter Structures: Implications for Conceptions Of Pedagogical Content Knowledge. Eurasia Journal of Mathematics, Science and Technology Education, 2(1), 1-29.

Aikenhead, G. (1987). High school graduates' beliefs about science-technology society. III. Characteristics and limitations of scientific knowledge. Science Education, 71(4), 459-487.

Aikenhead, G., Fleming, R. W. \& Ryan, A. G. (2013, Temmuz 2). CDN 5 form of VOSTS, http://www.usask.ca/education/people/aikenhead/vosts.pdf, 1989. (Erişim Tarihi: 2012, 2 Temmuz).

Altındağ, C. (2010). Bilimin Doğasını Öğretmen Adaylarına Öğretmeye Yönelik Bir Çalışma. Yayımlanmamış Yüksek Lisans Tezi. Pamukkale Üniversitesi, Denizli.

Altun Yalçın, S., Kahraman, S., Açışlı, S. \& Yılmaz, Z. A. (2010). Fen Bilgisi Öğretmen Adaylarının Bilimin Doğası Konusundaki Görüşlerinin Tespit Edilmesini. Erzincan Üniversitesi Sosyal Bilimler Enstitüsü Dergisi. 3(2), 181-197.

Arı, Ü. (2010). Fen Bilgisi Öğretmen Adaylarının ve Sınıf Öğretmen Adaylarının Bilimin Doğası Hakkındaki Görüşlerinin Incelenmesi. Yayımlanmamış Yüksek Lisans Tezi. Fırat Üniversitesi, Elazığ.

Aslan, O., Yalçın N. \& Taşar, M. F. (2009). Fen ve Teknoloji Öğretmenlerinin Bilimin Doğası Hakkındaki Görüşleri. Ahi Evran Üniversitesi Ĕ̆itim Fakültesi Dergisi. 10(3), 1-8.

Bell, R., Lederman, N. G. \& Abd-El-Khalick, F. (2000). Developing and Acting Upon 114 One's Conception of Nature Of Science: A follow-up study. Journal of Research in Science Teaching. 37, 563-581.

Beşli, B. (2008). Fen Bilgisi Öğretmen Adaylarının Bilim Tarihinden Kesitler Incelemelerinin Bilimin Doğası Hakkındaki Görüşlerine Etkisi. Yayımlanmamış Yüksek Lisans Tezi. Abant İzzet Baysal Üniversitesi, Bolu.

Briscoe, C. (1991). The Dynamic Interactions Among Beliefs, Role Metaphors And Teaching Practices. A Case Study of Teacher Change. Science Education. 75(2), 185-99.

Büyüköztürk, Ş. (2010). Sosyal Bilimler Iç̧in Veri Analizi El Kitabı. Pegem A.: Ankara

Çakır, Ç., N. (2012). Sınıf öğretmenlerinin bilimin doğasına ilişkin görüşleri ve bilimsel tutum ile fen öz yeterlik düzeyleri arasındaki ilişkinin incelenmesi: Kütahya örneği. Yayınlanmamış Yüksek Lisans Tezi. Uşak Üniversitesi, Uşak. 
Çepni, S., Ayvacı, H. Ş. \& Bacanak, A. (2006). Fen Eğitiminde Yeni Bir Bakış: Fenteknoloji- Toplum. Pegem Yayınc1lik: Trabzon.

Demirbaş, M., Bozdoğan E. A. \& Özbek, G. (2012). An Analysis from Different Variables of Views of Pre-Service Science Teachers in Turkey on the Nature of Science. Research Journal of Recent Sciences, 1(8), 29-35.

Doğan Bora, N. (2005). Türkiye Genelinde Ortä̈ğretim Fen Branşı Öğretmen ve Öğrencilerinin Bilimin Doğası Üzerine Görüşlerinin Araştırılması. Yayımlanmamış Doktora Tezi. Gazi Üniversitesi, Ankara.

Driver, R., Leach, J., Millar, R. \& Scott, P. (1996). Young People’s Images of Science, Open University Press, Buckingham.

Elby, A., \& Hammer, D. (2001). On the substance of a sophisticated epistemology. Science Education. 85(5), 554-567

Erdoğan, R. (2004). Investigation of the Preservice Science Teachers' Views on Nature of Science. Unpublished Master's Thesis. Middle East Technical University, Ankara.

Gürses, A., Doğar, Ç. \& Yalçın, M. (2005). Bilimin Doğası ve Yüksek Öğrenim Öğrencilerinin Bilimin Doğasına Dair Düşünceleri. Milli Eğitim Dergisi. 166.

Hand, B., Lawrence, C. \& Yore, L. D. (1999). A Writing in Science Framework Designed To Enhance science Literacy. International Journal of Science Education. 21(10), 1021-1035.

Hogan, K. (2000). Exploring A Process View of Students' Knowledge About The Nature Of Science. Science Education. 84, 51-70.

Kahyaoğlu, E. (2004). Turkish Preservice Science Teachers' Views on STS: Characteristics of Scientists' Work. Unpublished Master's Thesis. Middle East Technical University, Ankara.

Karasar, N. (2004). Bilimsel Araştırma Yöntemleri. Nobel: Ankara.

Kenar, Z. (2008). Fen Bilgisi Öğretmen Adaylarının Bilimin Doğası Hakkındaki Görüşleri. Yayımlanmamış Yüksek Lisans Tezi. Balıkesir Üniversitesi, Balıkesir.

Küçük, M. (2006). Bilimin Doğasını İlköğretim 7. Sinıf Öğrencilerine Öğretmeye Yönelik Bir Çalışma. Yayımlanmamış Doktora Tezi. Karadeniz Teknik Üniversitesi, Trabzon.

Lederman, N. G. (1992). Students' and Teachers' Conceptions of the Nature of Science: A Review of the Research. Journal of Research in Science Teaching. 29, 331-359.

Lederman, N. G., Abd-El-Khalick, F., Bell, R. L. \& Schwartz, R. S. (2002). Views of Nature of Science 131 Questionnaire: Toward valid and meaningful assessment of learners' conceptions of nature of science. Journal of Research in Science Teaching. 39, 497-521. 
Lederman, N.G. (2007). Nature of science: Past, present, and future. In S.K. Abell, \& N.G. Lederman, (Editors), Handbook of research in science education (pp 831-879). Mahwah, New Jersey: Lawrence Erlbaum Publishers.

Liu, S. Y. \& Lederman, N. G. (2007). Exploring Prospective Teachers’ Worldviews and Conceptions of Nature of Science. International Journal of Science Education. 29(10), 1281-1307.

Macaroğlu, E., Baysal, N. Z. \& Şahin, F. (1999). İlköğretim Öğretmen Adaylarının Bilimin Doğası Hakkındaki Görüşleri Üzerine Bir Araştırma. D.E. ̈̈ Buca Eğitim Fakültesi Dergisi. Özel Sayı. 10, 55-62.

Mccomas, W. F. (2000). The principal elements of the nature of science: dispelling the myths In W. F. McComas (Ed.), The nature of science in science education. Rationales and Strategies. Dordrecht, The Netherlands: Kluwer Academic.

M.E.B. (2005). İlköğretim Fen ve Teknoloji Dersi, 4-8 Sınıflar Öğretim Programı, Talim ve Terbiye Kurulu Başkanlığı, Ankara.

M.E.B. (2013). Fen Bilimleri Dersi Öğretim Programı ve Kılavuzu (3., 4., 5., 6., 7. ve 8. sinıflar). Ankara: Milli Eğitim Bakanlığı Talim ve Terbiye Kurulu Başkanlığg.

Moss, D. M., Abrams, E. D. \& Robb, J. (2001). Examining Student Conceptions of the Nature of Science. International Journal of Science Education. 23(8), 771-790.

Murcia, K. \& Schibeci, R. (1999). Primary Student Teacher' Conceptions of the Nature of Science. International Journal Of Science Education. 21(11), 1123-1140.

Niaz, M. (2009). Progressive Transitions İn Chemistry Teachers' Understanding of Nature of Science Based On Historical Controversies. Science \& Education 18, 3-65.

Özbudak, Z. (2010). Fen Bilgisi Öğretmen Adaylarının Bilimin Doğasını Anlama Düzeylerinin Tespit Edilmesi. Yayımlanmamış Yüksek Lisans Tezi. Kocaeli Üniversitesi, Kocaeli.

Özcan, I. (2011). Bilimin Doğası Inanışlarına Yönelik Bir Ölçeğin Geliştirilmesi ve Fen Bilgisi Öğretmen Adaylarının Bilimin Doğası Inanışlarının Tespiti. Yayımlanmamış Yüksek Lisans Tezi. Marmara Üniversitesi, İstanbul.

Palmquist, B. \& Finley, F. N. (1997). Preservice Teacher' Views of the Nature of Science During a Postbaccalaureate Science Teaching Program. Journal of Research in Science Teaching. 34(6), 595-615.

Reif, F. \& Larkin, J.H. (1991). Cognition in Scientific and Everyday Domains: Comparison and Learning Implications. Journal of Research in Science Teaching. 28(9), 733-760.

Ryan, A. G. \& Aikenhead, G. S. (1992). Students' Preconceptions about the Epistemology of Science, Science Education, 76, 559-580. 
Rubba, P. A., Bradford, C. S. \& Harkness, W. J. (1996). A New Scoring Procedure for The Views on Science-Technology-Society Instrument. International Journal of Science Education.18, 387-400.

Sadler, T. D., Chambers, F. W. \& Dana, L. Z. (2004). Student Conceptualizations of The Nature of Science in Response to A Socioscientific issue. International Journal of Science Education. 26(4), 387-409.

Saraç, E. (2012). Sınıf Öğretmenleri ve Sınıf Öğretmeni Adaylarının Bilimin Doğasına İlişkin Görüşleri. Yayımlanmamış Yüksek Lisans Tezi. Akdeniz Üniversitesi, Antalya.

Şahin, N., Deniz, S. \& Görgen, I. (2006). Student Teachers' Attitudes Concerning Understanding The nature Of Science in Turkey. International Education Journal, 7, 51-55.

Tatar, E., Karakuyu, Y. \& Tüysüz, C. (2011). Sınıf Öğretmeni Adaylarının Bilimin Doğası Kavramları Hakkındaki Yanlış Anlamaları. Buca Eğitim Fakültesi Dergisi. 29, 153-161.

Wong, D. E. (2002). To Appreciate Variation Between Scientist: A Perspective for Seeing Science's Vitality. Wiley Periodicals, International Science Education. 86, 386-400.

Yalvaç, B. \& Crawford, B. (2002). Eliciting prospective science teachers' conceptions of the nature of science in Middle East Technical University (METU), in Ankara. Paper presented at the annual meeting of the Proceedings of the 2002 Annual International Conference of the Association for he Education of Teachers in Science (pp. 228-266), Pensacola, FL. Association for he Education of Teachers in Science (ERIC Document Reproduction Service No. ED 465 602)

Yalçın, S. A. \& Yalçın, S. (2011). Analyzing Elementary Teachers' Views on The Nature of Science According to Their Academic Levels. Procedia Social and Behavioral Sciences. 15, 942-946.

Yenice, N. \& Saydam, G. (2010). The Views of the $8^{\text {th }}$ Grade Students About Nature Of Scientific Knowledge. Procedia Social and Behavioral Sciences, 2, 50125017.

Zeidler, D. L., Walker, K. A., Ackett, W. A. \& Simmons, M. L. (2002). Tangled Up in Views: Beliefs in the Nature of Science and Responses to Socioscientific Dilemmas. Science Education. 86, 343 - 367.

\section{Extended Summary}

In recent years scientific knowledge has been tremendeously expanded and the effects of technological advances on our life has become much more visible. Therefore, the current age necessitates those individuals who could correctly employ and comprehend science and scientific knowledge. As a result educational policies and programs attempt to produce those individiuals with higher levels of awareness on science and technology. Given that both classroom teachers and then science 
teachers have impartant roles to play in this regard the identification of both group of teachers' knowledge level about the nature of science and their misconceptions is required.

Aim

The aim of this study are to reveal the knowledge level about the nature of science among prospective science teachers and prospective classroom teachers and to analyse their views on the nature of science based on their field of study.

\section{Method}

The study was designed as a scanning research. The participants of the study are 142 prospective science teachers and prospective classroom teachers attending an university in the western part of Turkey. They were first grade and fourth grade undergraduate students. In order to reveal their views on the nature of science the VOSTS developed by Aikenhead, Ryan and Fleming (1989). It is composed of 114 multiple choice items and includes eight sections: "science and technology, the effects of society on science and technology, the effects of science and technology on society, characteristics of scientists, social nature of scientific knowledge, social nature of technology, and nature of scientific knowledge". Doğan Bora (2005) adapted it into Turkish and carried out relibility and validity analyses. Following the analyses the number of items was reduced to 25 and its internal consistency was found to be.72. The views of four specialists about the internal consistency of the items were also taken.

\section{Discussion and Conclusion}

The findings obtained indicated that the participants have realist views on the effects of society on science, the effects of science on society, characteristics of scientist, nature of observations, nature of classification systems, provisional nature of scientific knowledge and changeability of scientific knowledge. It was further found that their knowledge is not efficient in regard to the relationship between scientific discoveries and gender, nature of scientific models, relationship between hypothesis-theory-scientific laws and epistemological nature of scientific knowledge. In addition student science teachers were found to have much more realistic perspective in regard to the definition of science. They also reported much more realistic views about the effects of society on science which was evaluated by two items in the test. The same phenomena was expressed in a realistic but not efficient way by the student classroom teachers. It was concluded that both groups of student teachers had both realistic and inefficient views about the effects of science on society. The same finding was also found about the characteristics of 
N.Yenice,B.Özden... / EÜ Eğitim Fakültesi Dergisi,17(1)(2015), 237-281

scientists for both groups of participants. Both group of student teachers reported realistic views at the similar levels in regard to the beliefs of scientists: $82.9 \%$ of student science teachers and $83.3 \%$ of student classroom teachers. In regard to classifications made by scientists it was found that student science teachers $(50.0 \%)$ have much more realistic perspectives in contrast to student classroom teachers (40.9\%). Student classroom teachers $(50.0 \%)$ were found to have more realistic perspective about the changeability of scientific knowledge in contrast to student science teachers (40.9\%). Majority of the participants reported inefficient views about whether or not there is a hierarchy between hypothesis, theory and scientific laws: $84.2 \%$ of student science teachers and $93.8 \%$ of student classroom teachers. As indicated by McComas (2000) this misconceptions relies on the assumption that the scientific views have a hierarchical nature. Therefore, it can be argued that the participants have a traditional science perspective. Misconception of the hierarchical nature of hypothesis, theory and scientific law is also frequently reported in the literature. More than half of the participants as a whole reported realistic views about the certainty and vague nature of the scientific knowledge. Both groups had inefficient but acceptable views about epistemological nature of scientific nature. Furthermore, the field of study was found to have statististically significant effects on the subdimensions of the effects of society on science, the characteristics of scientists, and the nature of scientific knowledge. In other subdimensions both groups reported similar answers and therefore there was no statistically significant difference in this regard. 